\title{
Soil biogenic emissions of nitric oxide from a semi-arid savanna in South Africa
}

\author{
G. T. Feig ${ }^{1}$, B. Mamtimin ${ }^{1,3}$, and F. X. Meixner ${ }^{1,2}$ \\ ${ }^{1}$ Biogeochemistry Department, Max Planck Institute for Chemistry, 55020 Mainz, Germany \\ ${ }^{2}$ Physics Department, University of Zimbabwe, Harare, Zimbabwe \\ ${ }^{3}$ Institute of Geography Science and Tourism, Xinjiang Normal University, P. R. China
}

Received: 4 June 2008 - Published in Biogeosciences Discuss.: 7 July 2008

Revised: 4 November 2008 - Accepted: 4 November 2008 - Published: 12 December 2008

\begin{abstract}
Soils of arid and semi-arid ecosystems are important biogenic sources of atmospheric nitric oxide (NO), however, there is still a shortage of measurements from these systems. Here we present the results of a laboratory study of the biogenic emission of NO from four different landscape positions of the Kruger National Park (KNP), a large conservation area in a semi-arid region of South Africa. Results show that the highest net potential NO fluxes come from the low lying (footslope) landscape regions, which have the largest nitrogen stocks and highest rates of nitrogen input into the soil. Net potential NO fluxes from midslope and crest regions were considerably lower. The maximum release of $\mathrm{NO}$ occurred at fairly low soil moisture contents of $10 \%-20 \%$ water filled pore space. Using soil moisture and temperature data obtained in situ at the Kruger National Park flux tower site, net potential NO fluxes obtained in the laboratory were converted to field fluxes for each of the four landscape positions for the period 2003 to 2005 . The highest field NO flux is from footslope positions, during each of these years and emissions ranged from $1.5-8.5 \mathrm{~kg}$ ha a (in terms of mass of nitrogen). Remote sensing and Geographic Information Systems techniques were used to up-scale field NO fluxes on a regional basis indicating that the highest emissions occurred from the midslope positions, due to their large geographical extent in the considered research area. Emissions for the KNP Skukuza land type (56000 ha) ranged from $20 \times 10^{3} \mathrm{~kg}$ in 2004 to $34 \times 10^{3} \mathrm{~kg}$ in 2003 . The importance of landscape characteristics in the determination of regional biogenic NO soil emission is emphasized.
\end{abstract}

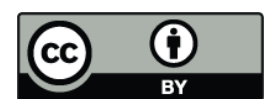

Correspondence to: G. T. Feig (feig@mpch-mainz.mpg.de)

\section{Introduction}

Emissions of nitric oxide (NO) and its conversion to nitrogen dioxide $\left(\mathrm{NO}_{2}\right)$ (collectively referred to as $\mathrm{NO}_{\mathrm{x}}=\mathrm{NO}+\mathrm{NO}_{2}$ ) are important in regulating chemical processes in the atmosphere (Crutzen, 1995; Crutzen and Lelieveld, 2001; Levine et al., 1997). Nitrogen oxides are key catalysts in the chemical processes that generate or destroy ozone. The ambient $\mathrm{NO}_{\mathrm{x}}$ mixing ratio is a threshold which determines whether ozone is generated or destroyed (Chameides et al., 1992; Crutzen and Lelieveld, 2001; Meixner and Yang, 2006). The ozone forming or destroying reactions of nitric oxide are also involved in chemical processes that result in the production or consumption of the hydroxyl radical $(\mathrm{OH})$, which is the chemical species most responsible for cleaning the atmosphere (Monks, 2005). Nitrogen oxides are removed from the atmosphere in a series of photochemical reactions that produce nitric acid (Monks, 2005). Nitric acid is an important component of acid deposition and acts as a source of $\mathrm{N}$ deposited from the atmosphere, in both the wet and dry form (Feig et al., 2007; Logan, 1983; Remde et al., 1993).

In 1860 it was estimated that the global $\mathrm{NO}_{\mathrm{x}}$ emission was $13.1 \mathrm{Tg} \mathrm{a}^{-1}$ (all values mentioned are in terms of mass of nitrogen), of which $10.5 \mathrm{Tg} \mathrm{a}^{-1}$ came from natural sources. By the early 1990s it was estimated that the emissions of $\mathrm{NO}_{\mathrm{x}}$ gases totalled $45.9 \mathrm{Tg} \mathrm{a}^{-1}$ (Galloway et al., 2004). The recent estimate of the Intergovernmental Panel on Climate Change is $42-47 \mathrm{Tg} \mathrm{a}^{-1}$ (Denman et al., 2007). The most important sources of $\mathrm{NO}_{\mathrm{x}}$ is fossil fuel combustion in power stations and vehicles (45\%-67\% of the total) (Denman et al., 2007; Kasibhatla et al., 1993) followed by lightning (5\%$16 \%)$ and biomass burning (13\%-29\%) with the biogenic emission from soil (either natural or under agriculture) accounting for between 10\% and $40 \%$ of the total (Davidson and Kingerlee, 1997; Denman et al., 2007). Nitrification has

Published by Copernicus Publications on behalf of the European Geosciences Union. 
long been considered the main source for $\mathrm{NO}$ from the soil (Conrad, 1996; Coyne, 1999; Davidson et al., 1993; Garrido et al., 2002; Remde et al., 1989; Russow et al., 2000; Russow et al., 2008; Stehfest and Bouwman, 2006; Tabachow et al., 2001). The proportion of nitrified $\mathrm{N}$ emitted as NO has been shown to range between 0 and $2.5 \%$ of the total $\mathrm{N}$ involved in nitrification (Garrido et al., 2002). While it is known that soil processes are responsible for a sizable proportion of the global $\mathrm{NO}_{\mathrm{x}}$ budget, there is considerable uncertainty about exactly how much. Davidson and Kingerlee (1997) provided a global inventory of $\mathrm{NO}$ emissions from soils, based on field measurements world-wide. Their estimate of the global NO soil source strength is $21 \mathrm{Tg} \mathrm{a}^{-1}$ (with an error margin of 4 to $10 \mathrm{Tg} \mathrm{a}^{-1}$ ), while the 4th IPCC estimate is $8.9 \mathrm{Tg} \mathrm{a}^{-1}$ (Denman et al., 2007) up from the 3rd IPCC estimate of $5.6 \mathrm{Tg} \mathrm{a}^{-1}$ (IPCC, 2001). The emission of NO from soil is affected by both biotic and abiotic factors; in addition, some ecosystems are better studied than others and therefore the quality of estimates differ between regions. While temperate regions and agricultural systems have been fairly well studied, a recent review by Meixner and Yang (2006) identified only 13 studies in natural drylands (annual precipitation below $400 \mathrm{~mm}$ ), since then there have been four other studies, one in Mongolia (Holst et al., 2007), one in Nevada (McCalley and Sparks, 2008) and one in Arizona (Hall et al., 2008). This is unfortunate since arid and semi-arid regions make up $40 \%$ of the earth's surface area (Veron et al., 2006) and are known to be an important potential source of biogenic NO emissions (Davidson et al., 1993).

The microbial activity controlling biogenic NO emissions and consumption from the soil is controlled by a number of factors including soil moisture, soil temperature and soil nutrient status (Conrad, 1994; Ludwig et al., 2001; Meixner et al., 1997). These in turn are largely controlled by geographic factors, for example the climatic conditions, the position in the landscape, the land use (Davidson, 1991b) and biological factors such as the vegetation.

In drier ecosystems, soil water seems to be the most important factor regulating emissions of NO. When the soil moisture is too low to maintain microbial activity there are very low levels of NO emitted (Garrido et al., 2002; Meixner et al., 1997) and when soil moisture level are too high to maintain aerobic conditions, the emission of NO is negligible (Skopp et al., 1990). The optimal emission of NO seems to occur at low soil moisture levels, but where microbial activity can still take place. In a previous field study in the Kruger National Park (KNP), NO emissions followed the predicted soil moisture curve where they were lowest at high $(>54 \%)$ and at low $(<8.7 \%)$ values of Water Filled Pore Space (WFPS) (Parsons et al., 1996). Even when desert soils are wetted, emissions of $\mathrm{N}$ containing gasses can occur with the maximum emission of NO occurring at fairly low soil moisture contents $(10 \%$ WFPS) (Hartley and Schlesinger, 2000).

A secondary controller of biogenic $\mathrm{NO}$ emissions is the soil nutrient status; many studies have found a relationship between the emissions of $\mathrm{NO}$ and either the concentrations of ammonia or nitrate (Erickson et al., 2001, 2002; Hartley and Schlesinger, 2000; Hutchinson et al., 1993; Ludwig et al., 2001; Meixner et al., 1997; Parsons et al., 1996) or the N cycling rate (Erickson et al., 2001, 2002; Hartley and Schlesinger, 2000; Parsons et al., 1996). Therefore, natural or anthropogenic actions that result in the modification of the inputs of nutrients or the rates of nutrient turnover are likely to have an effect on the NO production rates.

Catenal development is an important landscape process in many of the savanna regions of southern Africa, where the distribution of soil physical and chemical properties and vegetation community occurrence is determined by topographic position. Landscape processes, such as catenal development provide a natural example of a process that can control the distribution of moisture and nutrients across a landscape. Therefore the aim of this study was to determine the emission of NO across differing landscape positions in a semi-arid savanna ecosystem in southern Africa.

\section{Methods and materials}

\subsection{Site description}

This research occurred at the Kruger National Park (KNP) Flux Tower site $\left(25^{\circ} 01.184^{\prime} \mathrm{S}\right.$; $31^{\circ} 29.813^{\prime} \mathrm{E}$; $365 \mathrm{~m}$ above sea level) which is situated in a semi-arid savanna in the north eastern part of South Africa (Fig. 1a), $13 \mathrm{~km} \mathrm{WSW}$ of the tourist camp and administrative centre of Skukuza (for further details see Scholes et al. (2001)). It is a well characterised site that has been used in various other studies (Scholes et al., 2001). Exchanges of $\mathrm{CO}_{2}$, energy and $\mathrm{H}_{2} \mathrm{O}$ have been measured continuously since April 2000 using the eddy covariance technique (Harley et al., 2003; Scholes et al., 2001). Meteorological parameters have been measured at the main tower, while soil moisture and temperature has been measured at various depths in the two main surrounding ecosystem types since 2000. The flux tower is positioned exactly on the ecotone between a ridge-top broad-leafed Combretum savanna on sandy soil, dominated by Combretum apiculatum and Sclerocarya birrea and a midslope fine leaved Acacia savanna on clayey soil, dominated by Acacia nilotica, A. nigrescence and S. birrea. (Scholes et al., 2001) (as shown in Fig. 1b).

This characteristic catenal pattern is repeated throughout the wider region (Venter et al., 2003). The fine-leaved savannas have higher concentrations of soil nitrogen than the broad-leaved savannas (Table 1) (Scholes et al., 2003; Woghiren, 2002). The climate at the site is semi-arid subtropical with rainfall averaging $550 \mathrm{~mm}$ annually. Summers are hot and wet while winters are warm and dry (as shown in Fig. 2), for more detailed climatic information see Scholes et al. (2001) and Venter et al. (2003). 


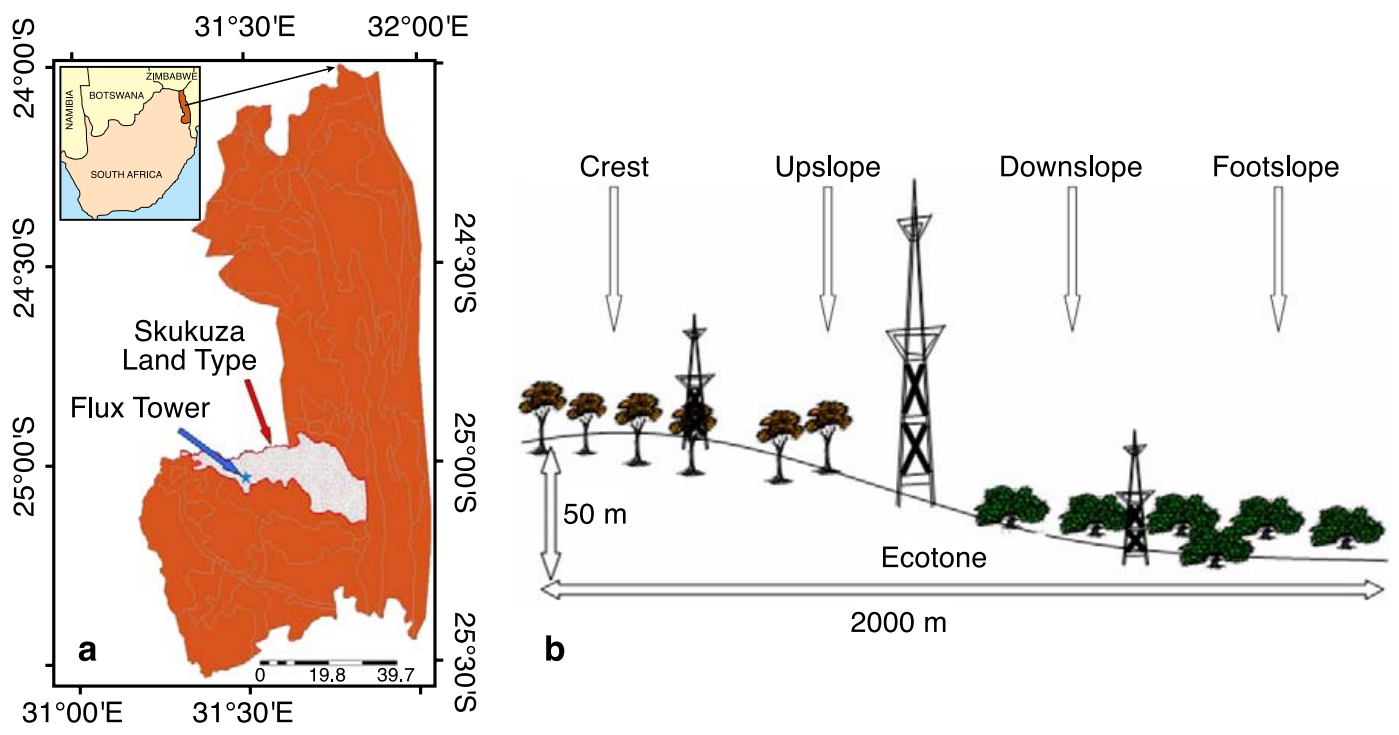

Fig. 1. (a) Map of the southern section of the Kruger National Park indicating the position of the Skukuza land type and the flux tower site, the position of the Kruger National Park in South Africa is shown in the insert. (b) A schematic diagram (not to scale) showing the position of the Skukuza flux tower in relation to the main ecosystem types, the smaller towers at the top and bottom of the slope are where the soil moisture and soil temperature measurements were taken.

Table 1. Physical and chemical properties of Skukuza KNP land type soils (all units are in terms of mass of N and mass of dry soil; numbers in brackets indicate the standard deviation of the measurements; values taken from Woghiren (2002) are marked by a star $(*)$ ).

\begin{tabular}{llllll}
\hline & Units & Footslope & Downslope & Upslope & Crest \\
\hline Bulk Density & $\mathrm{kg} \mathrm{m}^{-3}$ & $1.50 \times 10^{3}$ & $1.40 \times 10^{3}$ & $1.56 \times 10^{3}$ & $1.34 \times 10^{3}$ \\
Sand content & $\%$ & 66.8 & 74.9 & 72.8 & 72.8 \\
Silt content & $\%$ & 12.1 & 10.0 & 10.1 & 10.1 \\
Clay content & $\%$ & 21.1 & 15.1 & 17.2 & 17.1 \\
Texture & & Sandy Clay Loam & Sandy Loam & Sandy Loam & Sandy Loam \\
pH & & $6.25 \pm 0.06$ & $6.08 \pm 0.13$ & $6.36 \pm 0.06$ & $6.48 \pm 0.09$ \\
Total N & $\mathrm{kg} \mathrm{ha}^{-1}$ & 4635 & $\mathrm{ND}$ & $\mathrm{ND}$ & 3318 \\
Ammonium* & $\mu \mathrm{gg}^{-1}$ & $0.15-2.41$ & $\mathrm{ND}$ & $\mathrm{ND}$ & $1.38-2.72$ \\
Nitrate* & $\mu \mathrm{gg}^{-1}$ & $0.21-2.04$ & $\mathrm{ND}$ & $\mathrm{ND}$ & $0.01-1.24$ \\
Mean N & $\%$ & $0.08 \%(0.00)$ & $0.07 \%(0.01)$ & $0.05 \%(0.00)$ & $0.1 \%(0.01)$ \\
Mean C & $\%$ & $0.88(0.01)$ & $0.83(0.02)$ & $0.59(0.04)$ & $1.12(0.04)$ \\
Slope Class & $\%$ & $0-2 \%$ & $2-6 \%$ & $6-15 \%$ & $>15 \%$ \\
\hline
\end{tabular}

The soil physical and chemical properties are presented in Table 1 and include values reported by Woghiren (2002) and measurements conducted during this study. The soils are sandy loams in the "Crest" and midslope positions and sandy clay loams in the "Footslope" positions as determined through a sedimentation technique (Day, 1969). The soil $\mathrm{pH}$ was determined using the method of Anderson and Ingram (1993) and ranges from 6.1 to 6.5. The total C and N was measured at the Microanalytical laboratory at the University of Mainz using a Vario MICRO Cube universal microanalyser set up to measure total $\mathrm{C}, \mathrm{H}, \mathrm{N}$ and $\mathrm{S}$ content of our soil samples.

\subsection{Sampling and instrumental set up}

Soils were sampled in April 2005, using stainless steel soil cores with a length of $5 \mathrm{~cm}$ and radius of $2.5 \mathrm{~cm}$, from four landscape positions (see Fig. 1b); the "Crest", 20 m upslope of the "Ecotone" referred to as "Upslope", $20 \mathrm{~m}$ downslope of the "Ecotone", referred to as "Downslope" and the "Footslope". Soil samples were comprised of 10 sub-samples taken from the top $5 \mathrm{~cm}$ in each of the landscape positions, the ten samples were taken in a band parallel to the "Ecotone" at approximately $1 \mathrm{~m}$ intervals. The bulk samples were sieved through $2 \mathrm{~mm}$ mesh, air dried and then stored at $5^{\circ} \mathrm{C}$ until analysis. When soil is rewetted after a long period of 


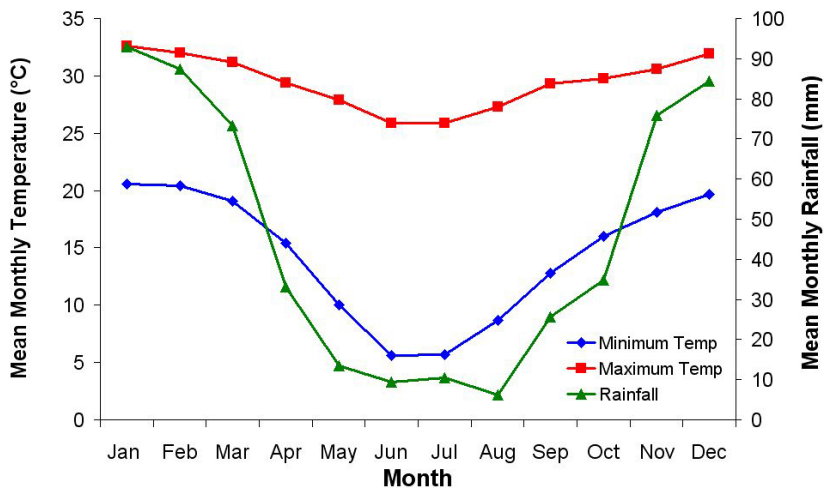

Fig. 2. Mean monthly minimum and maximum temperature and mean monthly precipitation at Skukuza for the period 1960-1999 as presented by Scholes et al. (2001).

inactivity there is often a large and rapid release of NO from the soil, either as the result of displacement of NO rich air from the soil or from the rapid mineralisation of readily available nitrogen sources. This pulsing effect (a) is of short duration and is not repeated or the magnitude is greatly reduced on subsequent rewetting (Kirkman et al., 2001; Otter et al., 1999; Scholes et al., 1997), and (b) may add to the total NO flux, but it is thought to be fairly insignificant, less than $6 \%$ of the annual NO flux (Scholes et al., 1997). Therefore, two days before beginning the laboratory analysis, an aliquot from the soil samples was soaked with deionised water and allowed to drain freely at room temperature $\left(22^{\circ} \mathrm{C}\right)$ to avoid the effect of pulsing after the initial wetting of soil after a long period of inactivity (Scholes et al., 1997; Snyder and Tartowski, 2006). The basic methodology for the laboratory measurement of NO flux from soil has been previously described (Aranibar et al., 2004; Kirkman et al., 2001; Meixner and Yang, 2006; Otter et al., 1999; Van Dijk et al., 2002) and is only briefly described here. A known mass of sieved, wetted soil (approximately $100 \mathrm{~g}$ dry weight) was placed in one of five Plexiglas chambers (volume $9.7 \times 10^{-4} \mathrm{~m}^{3}$ ) in a thermo-controlled cabinet (four chambers were used for soil samples while one was kept empty as a reference). Pressurised air that had passed through a purification system (four traps consisting of glass wool, activated charcoal, silica gel, and molecular sieve to provide a dry and "NO free" air stream) was supplied to each chamber at a flow rate of $4.2 \times 10^{-5} \mathrm{~m}^{3} \mathrm{~s}^{-1}\left(2.5 \mathrm{~L} \mathrm{~min}^{-1}\right)$, controlled by five mass flow controllers. The air in each chamber was well mixed using a Teflon coated fan (Micronel®, USA) in each chamber, flow rate $8.7 \times 10^{-4} \mathrm{~m}^{3} \mathrm{~s}^{-1}\left(52 \mathrm{~L} \mathrm{~min}^{-1}\right)$. The outlet of each chamber was connected via (a) a reverse nafion tube (Perma Pure ${ }^{\circledR}$ MD-125-127), and (b) a switching valve to a NO Chemiluminescence analyser (Eco Physics Switzerland, model CLD780TR) and a $\mathrm{H}_{2} \mathrm{O} / \mathrm{CO}_{2}$ analyser (Rosemont Analytical, USA, Binos IR gas analyser). Occasionally, nitric oxide standard gas (200 ppm) was diluted into the air purification system via a mass flow controller (Mass-Flo® $200 \mathrm{sccm}$ Range, MKS instruments, USA); this allowed (a) calibration of the NO Chemiluminescence analyser and (b) control of the chamber headspace NO concentration when determining NO uptake in the soil (see below). The soil moisture content was determined by tracking the loss of water vapour throughout the measurement period and relating it to the gravimetric soil moisture content at the start and end of the measurement period. The purpose of the reverse Nafion driers is (a) to keep the humidity of the chambers' headspace air high, and hence (b) to slow the dehydration of the soil, allowing the microbes in the soil time to equilibrate to changes in the soil moisture content.

\subsection{Measurements of the net, NO release rate}

The net release of NO $\left(J_{\mathrm{NO}}\right.$, in $\left.\mathrm{ng} \mathrm{kg}^{-1} \mathrm{~s}^{-1}\right)$ is calculated from the difference between the NO mixing ratio at the outlet of the reference cuvette and the outlet of each of the incubation cuvettes (since the air in the cuvette is well mixed, the air at the outlet is assumed to have the same composition as the air in the headspace) according to:

$$
J_{\mathrm{NO}}=\frac{Q}{M_{\text {soil }}}\left(m_{\mathrm{NO}, \text { out }}-m_{\mathrm{NO}, \text { ref }}\right) \times\left(\frac{M_{N}}{V_{m}} \times 10^{-3}\right)
$$

where $Q$ is the flow rate through the cuvette $\left(4.2 \times 10^{-5} \mathrm{~m}^{3} \mathrm{~s}^{-1}\right.$ or $\left.2.5 \mathrm{~L} \mathrm{~min}^{-1}\right), \quad M_{\text {soil }}$ is the dry mass of the soil $(\mathrm{kg}), M_{N}$ is the molar mass of $\mathrm{N} \quad\left(14.0076 \mathrm{~kg} \mathrm{kmol}^{-1}\right), \quad V_{m}$ is the molar volume $\left(24.465 \mathrm{~m}^{3} \mathrm{kmol}^{-1}\right.$ at $\left.25^{\circ} \mathrm{C} 1013.25 \mathrm{hPa}\right)$ and $m_{\mathrm{NO}}$,ref and $m_{\mathrm{NO}}$,out are the mixing ratios of $\mathrm{NO}$ in $\mathrm{ppb}$, at the outlets of the control and incubation cuvettes respectively (the factor $\mathrm{M}_{N} / \mathrm{V}_{m} \times 10^{-3}$ is needed to convert NO mixing ratio (ppb) to NO concentration $\left(\mathrm{ng} \mathrm{m}^{-3}\right)$ ).

The release of NO from the soil is the result of the microbial production and consumption of NO in the soil, processes that occur simultaneously (Conrad, 1994, 1995, 1996). As a result, the NO release rate $\left(J_{\mathrm{NO}}\right)$ is always a net release rate. However if the NO consumption is greater than production in the soil sample then $J_{\mathrm{NO}}$ becomes negative. This will only occur if the in-coming "(=reference)" NO mixing ratio is greater than the headspace NO mixing ratio in the soil containing chamber.

It has already been shown experimentally that there is a linear relationship between the NO release rate $\left(J_{\mathrm{NO}}\right)$ and the rate of NO production $(P)$ and consumption $(k)$ (Ludwig et al., 2001; Remde et al., 1989) so that the measured release rates can be described according to:

$J_{\mathrm{NO}}=P-k \times m_{\mathrm{NO}, \text { out }} \times\left(\frac{M_{N}}{V_{m}} \times 10^{-3}\right)$

This equation implies that the NO production is independent of the NO mixing ratio in the headspace $\left(m_{\mathrm{NO} \text {,out }}\right)$, while the NO consumption is dependent on the NO mixing ratio in the headspace, and can be approached as a 
first order decay process. To determine the values of $P$ and $k$, Eq. (2) was used with the measured release rates $\left(J_{\mathrm{NO}}\right)$ from two sets of incubation measurements, $m_{\mathrm{NO}, \mathrm{ref}}=0 \mathrm{ppb}$ and $m_{\mathrm{NO}, \mathrm{ref}}=58 \mathrm{ppb}$. This allowed us to calculate $P\left(\mathrm{ng} \mathrm{kg}^{-1} \mathrm{~s}^{-1}\right)$ and $k\left(\mathrm{~m}^{3} \mathrm{~kg}^{-1} \mathrm{~s}^{-1}\right)$, where $k$ can be determined from the slope of Eq. (2),

$k=\frac{\Delta J_{\mathrm{NO}}}{\Delta[\mathrm{NO}]}=\frac{J_{m, \mathrm{high}}-J_{m, \mathrm{low}}}{m_{\mathrm{high}}-m_{\mathrm{low}}} \times\left(\frac{V_{m}}{M_{N}} \times 10^{3}\right)$

where $m_{\text {low }}$ is the actual NO mixing ratio (ppb) in the head space of the cuvette under fumigation with NO free air and $m_{\text {high }}$ is the actual NO mixing ratio in the cuvette headspace under fumigation with $58 \mathrm{ppb}$ NO. In this study, we will present values of the NO release rate $\left(J_{\mathrm{NO}}\right)$ as a function of soil moisture, in terms of the soil WFPS. Water filled pore space is a useful concept because it indicates the amount of water in the soil that is available for microbial activity and also the amount of air in the soil and therefore the soil oxygen status. The WFPS is calculated (a) from the amount of water lost from the enclosed cuvettes through evaporation during the incubation process and (b) through determining the gravimetric water content $(\Theta)$ of the rewetted sample at the start of the incubation. The WFPS is calculated according to Eq. (4):

$\mathrm{WFPS}=\Theta \times \frac{\mathrm{BD}}{1-\frac{\mathrm{BD}}{\mathrm{PD}}}$

where BD is the soil bulk density in $\left(\mathrm{kg} \mathrm{m}^{-3}\right)$ measured at the site of sampling, by driving a stainless steel core of known volume driven into the soil and removing a soil sample and drying the soil at $105^{\circ} \mathrm{C}$ for $48 \mathrm{~h}$, and PD is the particle density of the average soil mineral (quartz) with a value of $2.65 \times 10^{3} \mathrm{~kg} \mathrm{~m}^{-3}$ according to Parton et al. (2001).

\subsection{Detection limit and estimation of the release rate error}

The detection limit of our laboratory technique was determined in a study by Gelfand et al (in prep), but is briefly described here. Inert glass beads and autoclaved Israeli desert soils were used to measure the "blank" net release of NO. It was found that the "blank" net release of NO from the glass beads was at a rate of $0.02 \mathrm{ng} \mathrm{kg}^{-1} \mathrm{~s}^{-1}$, with a random deviation of $0.02 \mathrm{ng} \mathrm{kg}^{-1} \mathrm{~s}^{-1}$ irrespective of the moisture content, therefore, we consider an experimentally derived detection limit for $J_{N O}$ of $0.08 \mathrm{ng} \mathrm{kg}^{-1} \mathrm{~s}^{-1}$ this results from the mean release rate of autoclaved soils plus 3 standard deviations (corresponding to a confidence interval of 99.7\%). Similarly, the detection limit of the autoclaved soils is $0.11 \mathrm{ng} \mathrm{kg}^{-1} \mathrm{~s}^{-1}$, therefore the more conservative estimate from the autoclaved soils is being used as our detection limit.

To quantify the precision of $J_{\mathrm{NO}}$ measurements, the NO net release rate was determined experimentally through the simultaneous measurement of four replicates across the full range of soil moisture. The mean standard deviation on the
NO net release rate was found to be $0.03 \mathrm{ng} \mathrm{kg}^{-1} \mathrm{~s}^{-1}$ irrespective of WFPS, this is lower than the experimentally derived detection limit of $J_{\mathrm{NO}}$ and we therefore consider $\pm 0.05 \mathrm{ng} \mathrm{kg}^{-1} \mathrm{~s}^{-1}$ as a conservative estimate of the experimentally derived precision of $J_{\mathrm{NO}}$.

\subsection{Calculation of the net potential NO flux}

The laboratory derived net release of $\mathrm{NO}\left(J_{\mathrm{NO}}\right.$, in $\left.n \mathrm{gg}^{-1} \mathrm{~s}^{-1}\right)$ from the soil was converted to a net potential NO flux ( $F_{\text {lab }}$, in $\mathrm{ng} \mathrm{m}^{-2} \mathrm{~s}^{-1}$ ) using a simple diffusion based algorithm (Eq. (5)), originally developed by Galbally and Johansson (1989), modified by van Dijk et al. (2002). The net potential laboratory NO flux, as a function of WFPS and $T_{\text {soil }}$, is calculated according to:

$$
\begin{aligned}
& F_{\text {lab }}\left(T_{\text {soil }}, \text { WFPS }\right)=\sqrt{\mathrm{BD} \times k\left(T_{\text {soil }}, \text { WFPS }\right) \times D(\mathrm{WFPS})} \\
& \times\left(\left(\frac{P\left(T_{\text {soil }}, \mathrm{WFPS}\right)}{k\left(T_{\text {soil }}, \mathrm{WFPS}\right)}\right)-[\mathrm{NO}]_{\text {Headspace }}\right)
\end{aligned}
$$

where $D$ (WFPS), in $\mathrm{m}^{2} \mathrm{~s}^{-1}$, is the WFPS dependent diffusion coefficient of NO through the soil which is calculated after Moldrup et al. (2000), from WFPS and the gas diffusion constant for free air $\left(\mathrm{m}^{2} \mathrm{~s}^{-1}\right)$ equal to $1.9 \times 10^{-5} \mathrm{~m}^{-2} \mathrm{~s}^{-1}$ (Gut et al., 1998), referenced to Lerman (1979), and where $[\mathrm{NO}]_{\text {Headspace }}$ is the NO concentration (in $10^{-12} \mathrm{~kg} \mathrm{~m}^{-3}$ ) in the headspace of the cuvette. The diffusion coefficient is dependent of the soil moisture content and the soil bulk density and therefore is calculated for each soil sample and each soil moisture interval.

For a given soil temperature, an algorithm has been developed (Meixner and Yang, 2006) to fit our net potential NO fluxes as a function of the WFPS (Eq. (6)). This algorithm describes the net potential NO flux as a power increase until optimal soil moisture followed by an exponential decrease:

$F_{\text {lab }}\left(T_{\text {soil }}=\right.$ const., WFPS $)=a$ WFPS $^{b} \exp (-c$ WFPS $)$

where parameters $a, b$ and $c$ are related to observed values by:

$$
\begin{aligned}
& a=\frac{F_{\mathrm{lab}}\left(\mathrm{WFPS}_{\mathrm{opt}}\right)}{\left[\mathrm{WFPS}_{\mathrm{opt}}^{b} \exp (-b)\right]} \\
& b=\frac{\ln \left[\frac{F_{\mathrm{lab}}\left(\mathrm{WFPS}_{\mathrm{opt}}\right)}{F_{\mathrm{lab}}\left(\mathrm{WFPS}_{\mathrm{upp}}\right)}\right]}{\ln \left(\frac{\mathrm{WFPS}_{\mathrm{opt}}}{\mathrm{WFPS}_{\mathrm{upp}}}\right)+\frac{\mathrm{WFPS}_{\mathrm{upp}}}{\mathrm{WFPS}_{\mathrm{opt}}}-1} \\
& c=\frac{-b}{\text { WFPS }_{\text {opt }}}
\end{aligned}
$$

where, for a given $T_{\text {soil }}$, WFPS $_{\text {opt }}$ is the soil moisture where the maximum laboratory NO flux is observed, $F_{\text {lab }}$ (WFPS opt ) is the maximum laboratory NO flux at the optimal 
soil moisture content, and WFPS ${ }_{\text {upp }}$ is the soil moisture content where $F_{\text {lab }}$ approximately equals zero $\left(F_{\text {lab }}\left(\mathrm{WFPS}_{\text {upp }}\right)\right.$ $=1 / 100 F_{\text {lab }}\left(\right.$ WFPS $\left.\left._{\text {opt }}\right)\right)$ for WFPS $>$ WFPS $_{\text {opt }}$.

The temperature dependence of the laboratory NO flux was determined by measuring the net potential laboratory NO flux at two soil temperatures, $25^{\circ} \mathrm{C}$ and at $35^{\circ} \mathrm{C}$. The temperature dependence usually shows an exponential increase and can be expressed as the increase of $F_{\text {lab }}$ for a $10^{\circ} \mathrm{C}$ increase in soil temperature, otherwise known as a $\mathrm{Q}_{10}$ function (Eq. (10); Lloyd and Taylor, 1994). In the midslope soils soil WFPS had a marked effect on the $\mathrm{Q}_{10}$ function of NO emission from the soil. However this effect was not consistent across all the soils and therefore the $\mathrm{Q}_{10}$ values used for this study were calculated from NO fluxes near the optimum soil moisture content.

$$
Q_{10}(\mathrm{WFPS})=\frac{F_{\text {lab }}\left(T_{\text {soil }}=35^{\circ} \mathrm{C}, \text { WFPS }\right)}{F_{\text {lab }}\left(T_{\text {soil }}=25^{\circ} \mathrm{C}, \text { WFPS }\right)}
$$

The $\mathrm{Q}_{10}$ function can then be included into Eq. (6), as a "temperature amplification factor" of the reference NO flux $\left(T_{\text {ref }}=25^{\circ} \mathrm{C}\right)$, so that the laboratory NO flux can be estimated as a function of both soil temperature and soil moisture (Eq. (11)):

$$
\begin{aligned}
& F_{\text {lab }}\left(T_{\text {soil }}, \text { WFPS }\right)=a_{\text {Tref }} \text { WFPS }^{b_{\text {Tref }}} \exp \left(-c_{\text {Tref }} \times \text { WFPS }\right) \\
& \times \exp \left[\frac{\ln Q_{10}(\mathrm{WFPS})}{10} \times\left(T_{\text {soil }}-T_{\text {ref }}\right)\right]
\end{aligned}
$$

\subsection{Compensation point mixing ratio}

The compensation point mixing ratio $\left(\mathrm{m}_{\mathrm{NO}, \mathrm{comp}}\right)$ is an important concept for the bi-directional exchange of NO (see Conrad, 1994). Since it determines what the ambient mixing ratio of NO in the atmosphere has to be before a net NO uptake into the soil can occur. The compensation point mixing ratio is calculated by resolving Eq. (5) for the NO concentration where $F_{\text {lab }}\left(\right.$ WFPS, $\left.T_{\text {soil }}\right)=0$ :

$m_{\mathrm{NO}, \text { comp }}\left(T_{\text {soil, }}, \mathrm{WFPS}\right)=\frac{P\left(T_{\text {soil }}, \mathrm{WFPS}\right)}{k\left(T_{\text {soil }}, \mathrm{WFPS}\right)} \times\left(\frac{V_{m}}{M_{N}} \times 10^{3}\right)$

\subsection{Up-scaling to the landscape positions}

Once we have derived the net potential NO flux $\left(F_{\text {lab }}\right)$ from our laboratory measurements as a function of both, soil moisture and temperature, the flux of NO from the four landscape positions ( $\left.F_{\mathrm{NO} \text {,up-scaled }}\right)$ at the KNP Tower site could be estimated by suitable up-scaling procedures using field data of soil temperature and moisture. For that we used the half hourly soil moisture and temperature data obtained from measurement stations within the fine-leaved savanna and the broad-leaved savanna, corresponding with the "Crest" and "Footslope" landscape positions and the soil $\mathrm{BD}$ and $\mathrm{D}$ values measured at each of the landscape positions. The $F_{\mathrm{NO} \text {,up-scaled }}$ from the two midslope positions was approached by the soil moisture and temperature data from the closest measurement site (the "Crest" for the "Upslope" position and the "Footslope" for the "Downslope" position). These soil moisture and temperature data were used in Eq. (11) to calculate the up-scaled flux on a half hourly basis. These half-hourly flux estimates were used to calculate monthly averages of $F_{\mathrm{NO} \text {,up-scaled }}$.

\subsection{Up-scaling to the landscape scale}

The Kruger National Park (KNP) Geographical Information System (GIS) data base divides the Skukuza land system (56 000 ha) into 3 landscape positions; the "Crest" comprising $12 \%$ of the surface area (6720 ha), the midslope comprising $80 \%$ of the surface area (44 $800 \mathrm{ha}$ ), and the "Footslope", comprising $8 \%$ of the surface area ( $4480 \mathrm{ha}$ ). Since the midslope landscape position encompasses both, the "Downslope" and "Upslope" sites of our sampling scheme, the midslope area was divided equally between the "Downslope" and "Upslope" sites, giving each $40 \%$ of the land type surface area (22 400 ha). The monthly average NO fluxes for each of our designated landscape positions (Sect. 2.7) were apportioned according to the proportion that each of the landscape positions comprised of the total Skukuza land type Venter et al. (2003) to estimate a total emission for the Skukuza land type for the years 2003-2005. This technique assumes that the soil BD, the soil temperature and soil moisture are the same across the whole region, for this reason the up-scaling attempt that we have made is limited to the Skukuza land type which is where the flux tower is situated, and where we can assume with reasonable confidence that on the whole similar conditions occur.

To assess the potential distribution of $\mathrm{NO}$ emissions from the Skukuza land type the landscape positions were associated with differing slope classes (Venter et al., 2003) as shown in Table 1 (bottom line). Shuttle Radar Tomography Mission (SRTM) digital elevation data (supplied by the Consortium for Spatial Information, of the Consultative Group for International Agricultural Research (CGIARCSI)) for the classification of the slope classes was used and incorporated into a geographical information system (GIS) database to give the distribution of the landscape classes for the Skukuza land type (Fig. 7). The annual point NO fluxes associated with the individual landscape positions were then assigned to the corresponding slope classes to provide a distribution of the annual NO emission from the various landscape positions of the Skukuza land type.

\section{Results}

\subsection{General behaviour of the net potential NO fluxes $\left(\mathrm{F}_{\text {lab }}\right)$}

For the reference soil temperature of $25^{\circ} \mathrm{C}$, an overview of the maximum derived net potential fluxes $\left(F_{\text {lab }}\right)$ and the $\mathrm{Q}_{10}$ values are given in Table 2. At $25^{\circ} \mathrm{C}$ the maximum $F_{\text {lab }}$ ranged from $1.3 \mathrm{ng} \mathrm{m}^{-2} \mathrm{~s}^{-1}$ in the "Downslope" soil to 
Table 2. Optimum soil moisture, maximum NO flux and $\mathrm{Q}_{10}$ value of Skukuza KNP land type soils (mass units are in terms of mass of $\mathrm{N}) ;\left(^{*}\right)$ measurement failed $\left(\mathrm{Q}_{10}=2.17\right.$ is used for the "Crest" soil).

\begin{tabular}{|c|c|c|c|c|}
\hline & Footslope & Downslope & Upslope & Crest \\
\hline Optimum WFPS at $25^{\circ} \mathrm{C}$ & $17 \%$ & $14 \%$ & $11 \%$ & $12 \%$ \\
\hline $\begin{array}{l}\text { Maximum net potential NO } \\
\text { flux at } 25^{\circ} \mathrm{C}\left(\mathrm{ng} \mathrm{m}^{-2} \mathrm{~s}^{-1}\right)\end{array}$ & 2.4 & 1.3 & 1.7 & 1.5 \\
\hline Optimum WFPS at $35^{\circ} \mathrm{C}$ & $18 \%$ & $17 \%$ & $18 \%$ & $18 \%$ \\
\hline $\begin{array}{l}\text { Maximum net potential NO } \\
\text { flux at } 35^{\circ} \mathrm{C}\left(\mathrm{ng} \mathrm{m}^{-2} \mathrm{~s}^{-1}\right)\end{array}$ & 3.5 & 3.0 & 3.5 & No Data \\
\hline $\mathrm{Q}_{10}$ Value & 1.55 & 2.11 & 2.17 & $(*)$ \\
\hline
\end{tabular}

$2.4 \mathrm{ng} \mathrm{m}^{-2} \mathrm{~s}^{-1}$ in the "Footslope". At $35^{\circ} \mathrm{C}$ the laboratory NO flux ranged from $3.1 \mathrm{ng} \mathrm{m}^{-2} \mathrm{~s}^{-1}$ in the "Downslope" soil to $3.5 \mathrm{ng} \mathrm{m}^{-2} \mathrm{~s}^{-1}$ in the "Upslope" soil. With the full temperature dependence included, the net potential NO fluxes were calculated for the four landscape positions as a function of soil moisture and temperature and are shown in Fig. 3a-d. Differences in the graphs reflect the differing emission potential as a function of soil WFPS and soil temperature for the individual soils. The highest $F_{\mathrm{lab}}$ occurs in the "Footslope", where at $40^{\circ} \mathrm{C}$ the $F_{\text {lab }}$ is $3.2 \mathrm{ng} \mathrm{m}^{-2} \mathrm{~s}^{-1}$, while the lowest $F_{\text {lab }}\left(2.5 \mathrm{ng} \mathrm{m}^{-2} \mathrm{~s}^{-1}\right)$ occurred in the "Downslope" at $40^{\circ} \mathrm{C}$.

The maximum $F_{\text {lab }}$ for all four landscape positions was calculated to lie between $10 \%$ and 20\% WFPS, (Table 2). The optimum WFPS differed according to the temperature of incubation. At $25^{\circ} \mathrm{C}$, it ranged from $11 \%$ for the "Upslope" position to $17 \%$ in the Footslope. The optimum WFPS was always greater under the higher incubation temperatures and occurred at 18\% WFPS ("Footslope", "Downslope", "Upslope") at $35^{\circ} \mathrm{C}$. Maximum $F_{\text {lab }}$ differed according to the incubation temperature and increased in the "Footslope", and the two midslope positions. The measurement of $F_{\text {lab }}$ at $35^{\circ} \mathrm{C}$ from the "Crest" soil was unsuccessful, since the aliquot of the corresponding soil sample got wet during the storage period between the measurements at $25^{\circ} \mathrm{C}$ and $35^{\circ} \mathrm{C}$. Therefore, the $\mathrm{Q}_{10}$ value for the "Upslope" site was used for the "Crest" site to estimate the temperature dependence during subsequent up-scaling calculations.

The maximum NO consumption constant $(k)$, calculated from Eq. (3) as a function of $T_{\text {soil }}$ and WFPS, occurs at approximately the same WFPS as the maximum of $F_{\text {lab }}$ (see Fig. 4), namely between $10 \%-25 \%$ WFPS. The highest NO consumption occurs in the "Footslope" soils $\left(2.7 \times 10^{-4} \mathrm{~m}^{3} \mathrm{~kg}^{-1} \mathrm{~s}^{-1}\right)$ while the consumption of the midslope and "Crest" soils appears to be similar and less than $1 \times 10^{-4} \mathrm{~m}^{3} \mathrm{~kg}^{-1} \mathrm{~s}^{-1}$. In all the soils the $k$ values were higher at the lower incubation temperatures.

The compensation point mixing ratio $\left(\mathrm{m}_{\mathrm{NO} \text {,comp }}\right)$ was calculated according to Eq. (12) from laboratory measurements

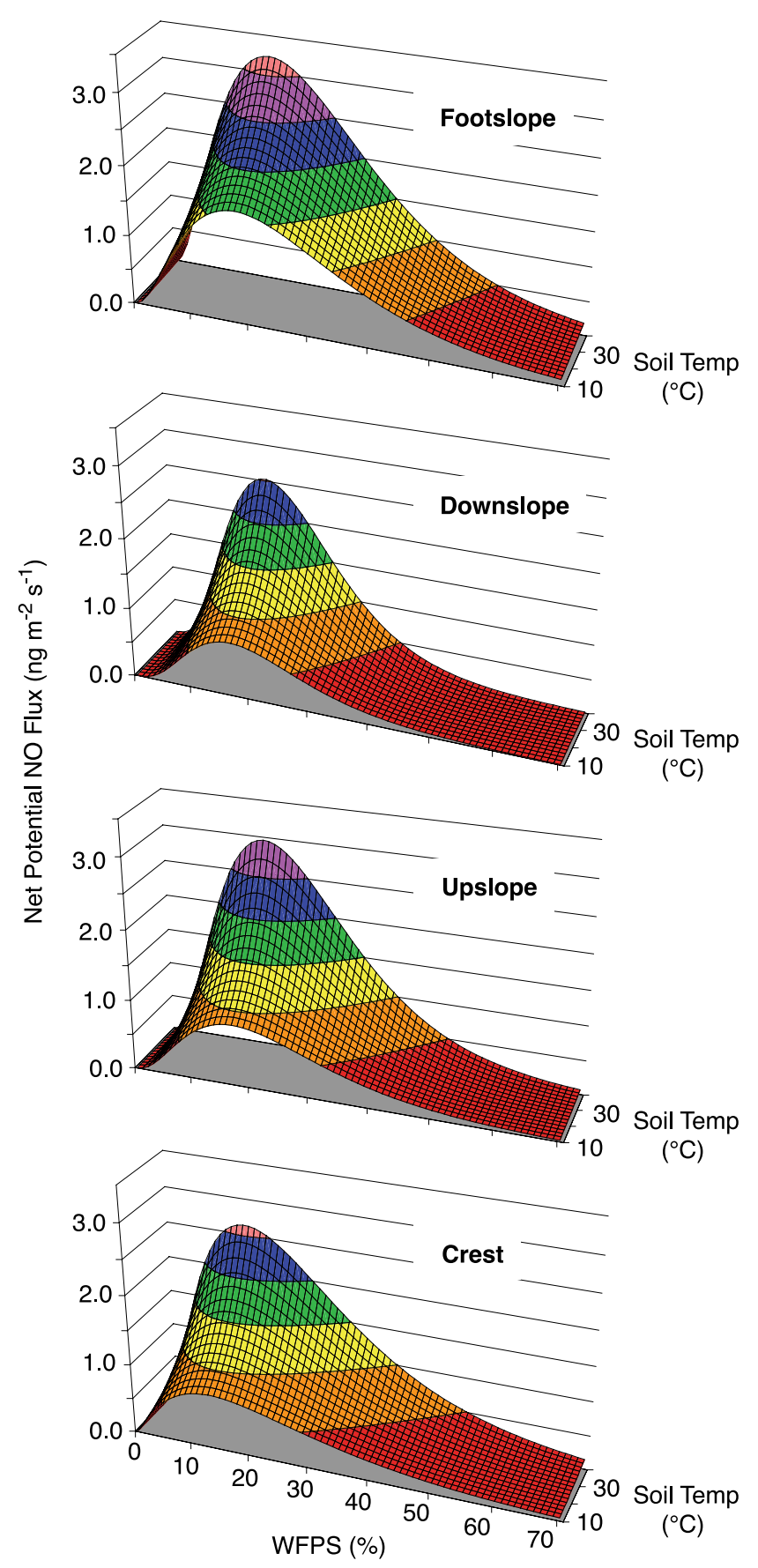

Fig. 3. Net potential NO flux $\left(F_{\text {lab }}\right)$ from the four landscape positions, "Footslope", "Downslope", "Upslope", and "Crest" as a function of soil moisture (WFPS) and soil temperature (mass of NO is expressed in terms of mass of nitrogen).

derived data of $P$ and $k$ (each as function of $T_{\text {soil }}$ and WFPS). If ambient NO equals $\mathrm{m}_{\mathrm{NO}}$,comp, then there is no net uptake or release of NO from the soil, since the production of NO equals the NO consumption in the soil. Figure 5 shows that $\mathrm{m}_{\mathrm{NO} \text {,comp }}$ at $25^{\circ} \mathrm{C}$ in each of the soils varies according to the soil moisture. The highest $\mathrm{m}_{\mathrm{NO}}$,comp occurs 


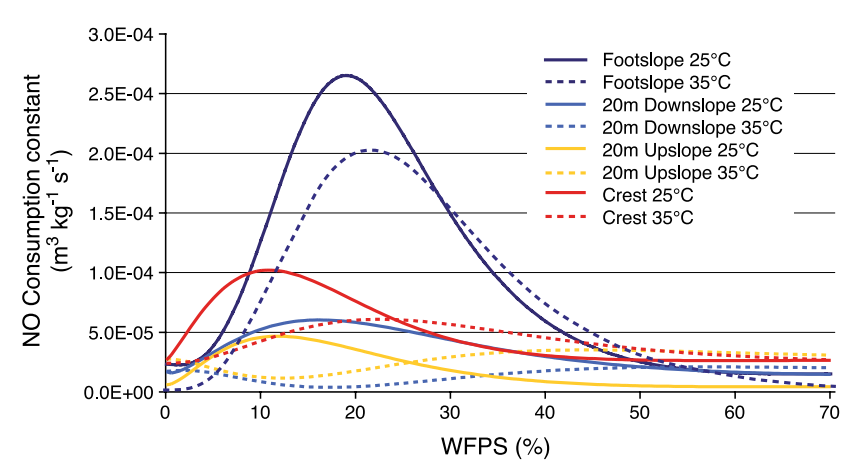

Fig. 4. NO consumption rate $(k)$ as a function of WFPS for the 4 landscape positions at $25^{\circ} \mathrm{C}$ and at $35^{\circ} \mathrm{C}$, solid lines represent the $k$ values at $25^{\circ} \mathrm{C}$, while the dashed lines represent $k$ at $35^{\circ} \mathrm{C}$.

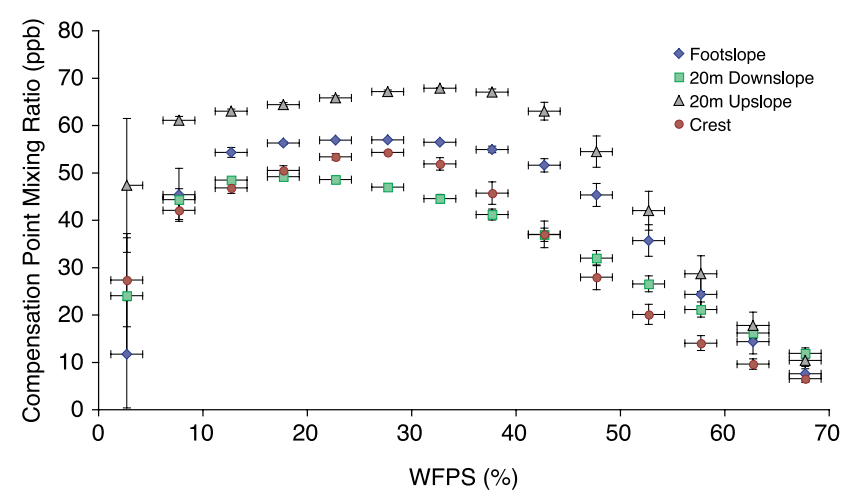

Fig. 5. Compensation point mixing ratio $\left(m_{\mathrm{NO}}\right.$, comp $)$ at $T_{\text {soil }}=25^{\circ} \mathrm{C}$ as a function of WFPS for soils of the four landscape positions in the Kruger National Park.

in the "Upslope" soils where a $\mathrm{m}_{\mathrm{NO}}$, comp of approximately $65-70 \mathrm{ppb}$ is reached at $35 \%$ WFPS. The "Footslope" soils have the next highest $\mathrm{m}_{\mathrm{NO}}$,comp, with a peak of 55-60 ppb at $40 \%$ WFPS. The "Crest" and "Downslope" have a maximum $\mathrm{m}_{\mathrm{NO}}$,comp between 45 and $50 \mathrm{ppb}$ at $20 \%$ WFPS for the "Downslope" and $27 \%$ WFPS for the "Crest".

\section{2 $T_{\text {soil }}$, WFPS, and $\mathrm{F}_{\mathrm{NO} \text {, up-scaled }}$ at different landscape positions}

Monthly mean soil temperature and volumetric soil moisture measured at $0.05 \mathrm{~m}$ depth at the Skukuza flux tower site are shown in Fig. 6 for the period 2003-2005.

The average monthly soil temperature ranged from $16.5^{\circ} \mathrm{C}$ to $36.5^{\circ} \mathrm{C}$ in winter and summer respectively (Fig. $6 \mathrm{~b}$ and c). There was little difference between the soils in the Acacia savanna ("Footslope" position) and the soils in the Combretum savanna ("Crest" position); although in the winter months the Combretum soils tend to be slightly cooler. As there was only one measuring site in each vegetation type it is not known whether this is due to small-scale variability or whether it reflects a true difference.
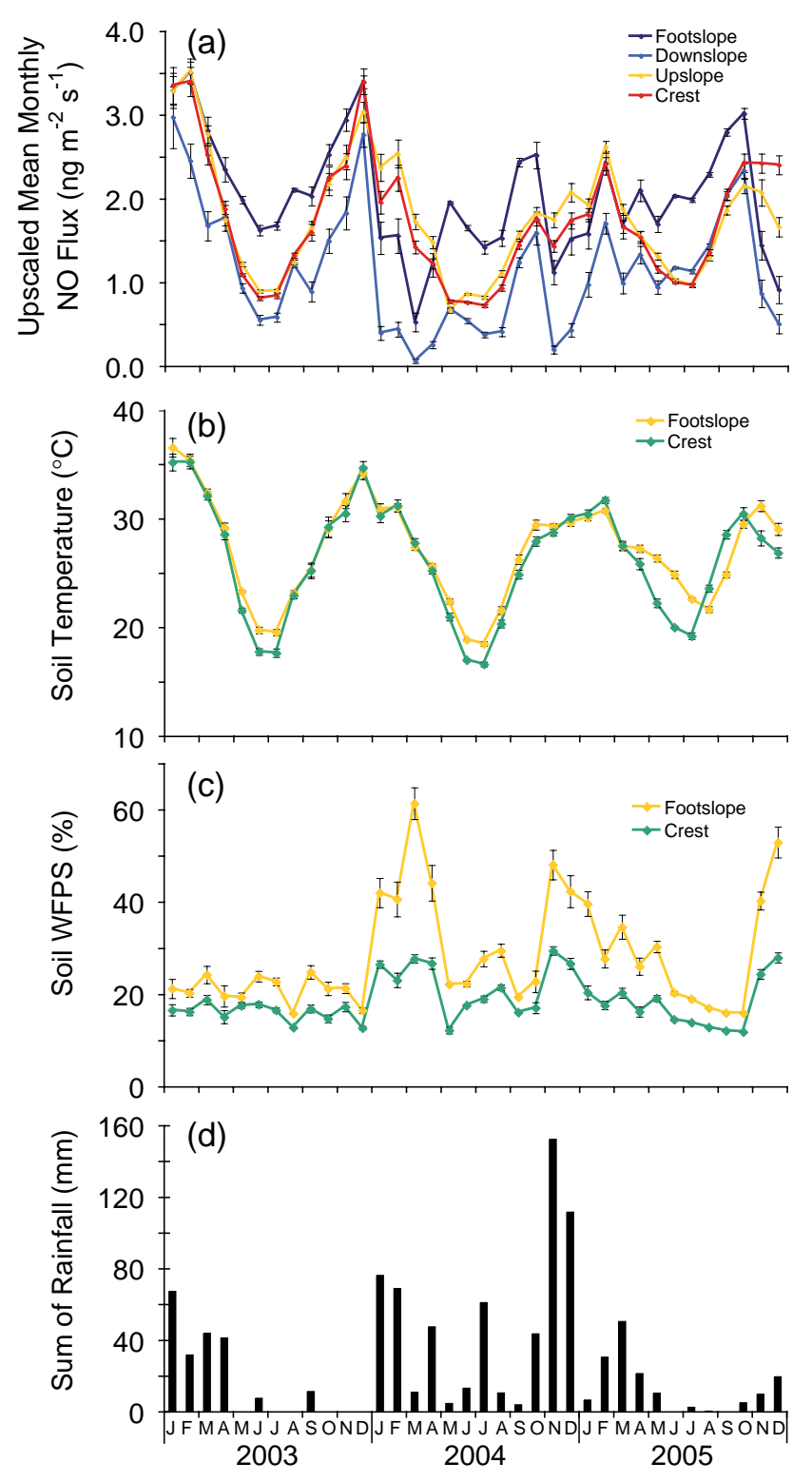

Fig. 6. (a) Monthly averages of the NO flux ( $F_{\mathrm{NO}}$,up-scaled $)$ from soils of the four landscape positions calculated for the period January 2003-October 2005 (error bars represent the daily variability expressed as standard error of the daily averages; mass of NO expressed in terms of mass of nitrogen)). (b) Recorded soil temperature for the period 2003-2005. (c) Recorded soil moisture (WFPS) for the period 2003-2005 average monthly soil moisture contents and temperatures calculated from half hourly recordings in the fineleaved Acacia savanna ("Footslope"), and the broad-leaved Combretum ("Crest"). Error bars indicate the monthly variability of the measurements (expressed as standard error). (d) Rainfall for the period 2003-2005.

In the "Footslope" soils there was always a higher soil WFPS than in the "Crest" soils (Fig. 6c), although they generally tracked each other quite closely during the dry periods. 


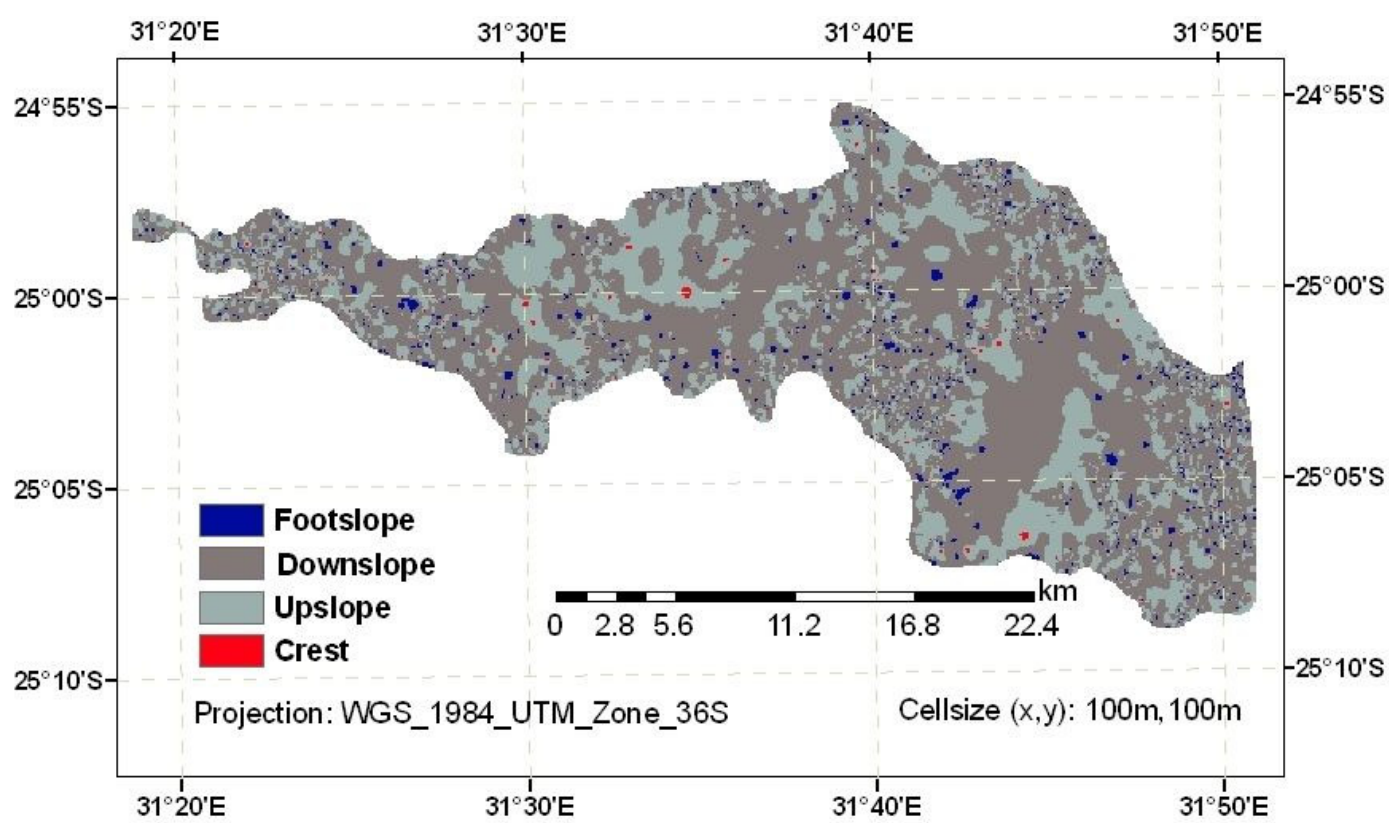

Fig. 7. Map of the Skukuza land type showing the distribution of the different landscape positions.

However in the high rainfall periods (January-March 2004, December 2004-May 2005 and November-December 2005, see Fig. 6d), the WFPS in the lower lying Footslope soils was much higher than that of the "Crest" soils. This is due to the drainage effects of the slope which resulted in water accumulating in the lower slope positions and the higher clay content of the "Footslope" would increase the water holding capacity of the "Footslope" soil.

Net up-scaled mean monthly NO fluxes $\left(F_{\mathrm{NO} \text {,up-scaled }}\right)$ at the four landscape positions were estimated from $T_{\text {soil }}$ and WFPS and are shown in Fig. 6a for the period 2003-2005. In these soils, $F_{\text {up-scaled }}$ ranges from less than the minimum detectable flux up to $3.5 \mathrm{ng} \mathrm{m}^{-2} \mathrm{~s}^{-1}$ and differs between the landscape positions (Fig. 6a). The $F_{\text {up-scaled }}$ for the "Downslope" was generally lowest and never exceeded $3 \mathrm{ng} \mathrm{m}^{-2} \mathrm{~s}^{-1}$. The $F_{\text {up-scaled }}$ is higher for the "Footslope" area than for the "Crest" and the "Upslope" soils except for a few periods during months of heavy rainfall (see Fig. 6d). During these periods, the highest $F_{\text {up-scaled }}$ came from the soils above the flux tower. The "Crest" and the "Upslope" soils generally followed a similar pattern, although the $F_{\text {up-scaled }}$ from the "Upslope" soils tended to be slightly higher.

Of the four landscape positions the "Footslope" soils produced the highest NO emissions per unit area over the 20032005 period, between 0.5 and $0.8 \mathrm{~kg} \mathrm{ha}^{-1} \mathrm{a}^{-1}$ (Fig. 8).

3.3 Estimates of NO emissions for the Skukuza land type area

When the area based annual NO fluxes were up-scaled to the entire Skukuza land type (Fig. 9), the total NO

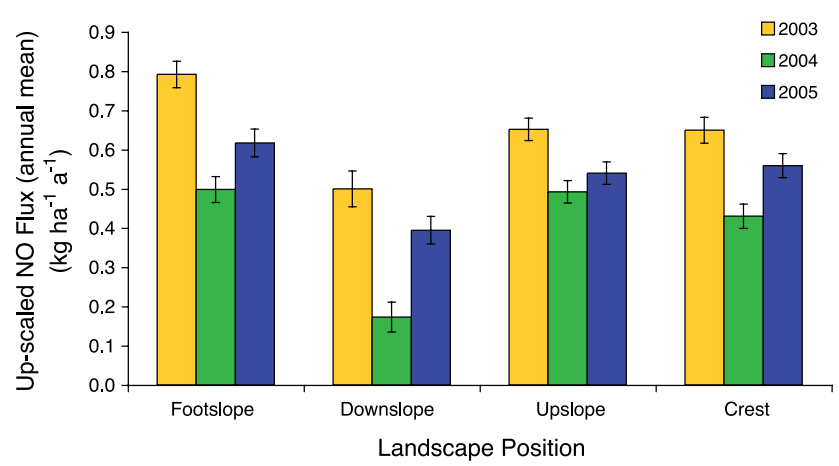

Fig. 8. Annual means of the up-scaled NO fluxes ( $\left.F_{\mathrm{NO}, \text { up}- \text { scaled }}\right)$ from soils of the 4 landscape positions for the period 2003-2005; error bars represent the standard deviation of the means (mass, of $\mathrm{NO}$ is expressed in terms of mass of nitrogen).

emission was $33.7 \times 10^{3} \mathrm{~kg}$ in $2003,20.0 \times 10^{3} \mathrm{~kg}$ in 2004 , and $27.4 \times 10^{3} \mathrm{~kg}$ in 2005 (all in terms of mass of nitrogen). Between the individual landscape positions (Footslope, Downslope, Upslope and Crest) no significant differences in the up-scaled mean annual NO flux $(p>0.05)$ were observed for the period 2003-2005. When the total summed emission for the Skukuza land type is divided into the constitutive land landscape positions of the original Kruger National Park (KNP) Geographical Information System (GIS) data base, the midslope positions (="Upslope"+"Downslope") accounted for the majority of the emissions, due to their greater geographical extent, over the three year period the Upslope landscape position were significantly higher $(p<0.01)$ than the Crest or the Footslope positions. 


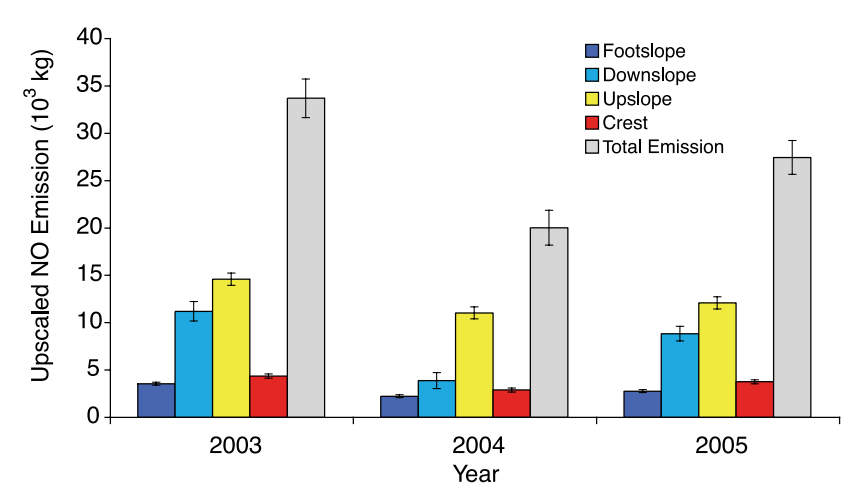

Fig. 9. Total area weighted NO emissions (expressed in terms of mass of nitrogen) from each of the four landscape positions in the Skukuza land type for the period 2003 to 2005; errorbars represent the standard deviation of the means.

\section{Discussion}

\subsection{Net potential NO fluxes}

In Fig. 10, we compare previously reported laboratory and field measurements of $\mathrm{NO}$ emissions from arid and semi-arid ecosystems with our net potential NO fluxes for the different landscape positions along a catenal sequence in the southern African Savanna of KNP. There have been two previous studies in the KNP, both of which were based on the use of field chambers (Levine et al., 1996; Parsons et al., 1996). In both studies, which occurred on long term fire return frequency experiments approximately $30 \mathrm{~km}$ away from the Skukuza flux tower, the measured NO field flux was between $0.34 \mathrm{ng} \mathrm{m}^{-2} \mathrm{~s}^{-1}$ and $32 \mathrm{ng} \mathrm{m}^{-2} \mathrm{~s}^{-1}$ at a range of soil moistures from $8.7 \%$ to 54\% WFPS (Levine et al., 1996; Parsons et al., 1996). The higher values reported in the Levine et al. (1996) paper (see Fig. 10) can be attributed to measurements occurring under artificially irrigated conditions, which resulted in an increase in the emission of NO from the soil.

Three laboratory based measurements, similar to the method used in this study, have been made in southern Africa, these include studies in Nylsvley Savanna (Otter et al., 1999), the Kalahari transect (Aranibar et al., 2004) and in Zimbabwe (Kirkman et al., 2001). In the Nylsvley Savanna in South Africa the NO flux ranged from $0.9-8 \mathrm{ng} \mathrm{m}^{-2} \mathrm{~s}^{-1}$ (Otter et al., 1999). For the study at Marondera (Zimbabwe) the NO flux ranged from $0.1-3.7 \mathrm{ng} \mathrm{m}^{-1} \mathrm{~s}^{-1}$ at soil moisture levels of between 9 and 15\% WFPS (Kirkman et al., 2001). In a rainfall gradient transect measurement through the Kalahari it was found that the NO flux ranged from 0 to over $120 \mathrm{ng} \mathrm{m}^{-2} \mathrm{~s}^{-1}$ (Aranibar et al., 2004) although it should be noted that these values are a much higher than from the other similar sites (see Fig. 10).

In other natural arid and semi-arid regions (mean annual precipitation $<700 \mathrm{~mm}$ ) the measured median NO fluxes range from $0.07 \mathrm{ng} \mathrm{m}^{-2} \mathrm{~s}^{-1}$ to $5.3 \mathrm{ng} \mathrm{m}^{-2} \mathrm{~s}^{-1}$ (with reported

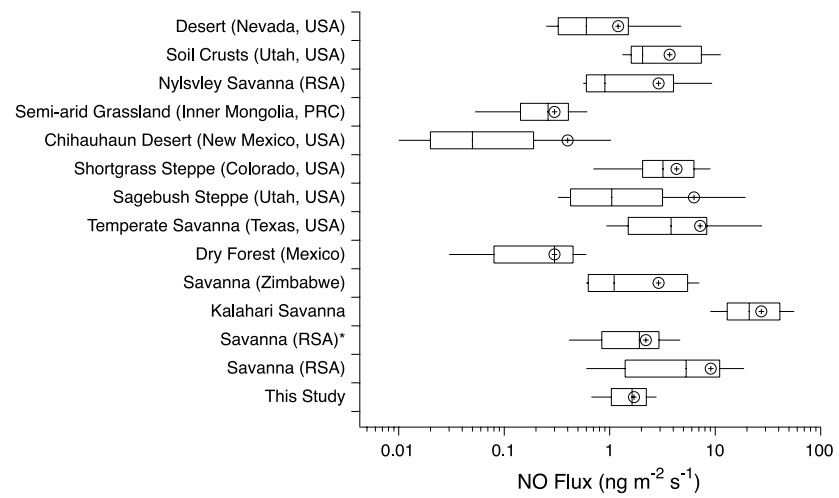

Fig. 10. Comparison of the up-scaled NO fluxes with data reported in the literature for comparable arid and semi arid ecosystems (all expressed in terms of mass of nitrogen). Boxes in the figure indicate the inter-quartile range between the 25 and 75 percentile and the median value is marked by a vertical bar. The (horizontal) error bars represent the 10 and 90 percentile. The open circle represents the arithmetic mean of the reported data. Where the cited papers provide a mean and range of data only, values were statistically recreated to match these ranges. The reported ecosystem NO flux data is cited from:

- Desert (Nevada, USA) (McCalley and Sparks, 2008);

- Soil Crusts (Utah, USA) (Barger et al., 2005);

- Nylsvley Savanna (RSA) (Otter et al., 1999);

- Semi-arid Grassland (Inner Mongolia, PRC) (Holst et al., 2007);

- Chihuahuan Desert ((New Mexico, USA) (Hartley and Schlesinger, 2000);

- Shortgrass Steppe (Colorado, USA) (Martin et al., 1998);

- Sagebush Steppe (Utah, USA) (Smart et al., 1999);

- Temperate Savanna (Texas, USA) (Martin et al., 2003);

- Dry Tropical Forest (Mexico) (Davidson et al., 1993);

- Savanna (Zimbabwe) (Kirkman et al., 2001);

- Kalahari Savanna (southern Africa) (Aranibar et al., 2004);

- Savanna (RSA)* (Parsons et al., 1996);

- Savanna (RSA) (Levine et al., 1996).

values of up to $83 \mathrm{ng} \mathrm{m}^{-2} \mathrm{~s}^{-2}$ occurred during a pulsing event, such as when the soil is wetted or fertilized) (Davidson et al., 1993; Hartley and Schlesinger, 2000; Holst et al., 2007; Martin and Asner, 2005; Martin et al., 1998; Smart et al., 1999), the Aranibar et al. (2004) study showed a median value of $21 \mathrm{ng} \mathrm{m}^{-2} \mathrm{~s}^{-1}$ and is far out of the range of other reported values (Fig. 10). Therefore in comparison with the other published studies in arid and semi-arid ecosystems the net potential NO fluxes $\left(F_{\text {lab }}\right)$ from this study are within the range reported for both field and laboratory measurements of NO and there is only a statistically significant difference $(p<0.05)$ between the values reported in this study and those 
reported in Levine et al. (1996), Aranibar et al. (2004) and Martin et al. (2003). The NO fluxes from these arid and semi-arid ecosystems tend to be fairly low in comparison with some of the values reported from "nitrogen amended" temperate forests where fluxes of $22 \mathrm{ng} \mathrm{m}^{-2} \mathrm{~s}^{-1}$ (Pilegaard et al., 2006) were reported in European coniferous forests during the NOFRETETE project.

\subsection{Effect of landscape and vegetation}

The biogenic emission of NO is controlled by the soil moisture, soil temperature and the soil nutrient status; it is through the combined effects of altering these modifiers of NO emission that landscape factors and vegetation can influence the production of NO from soils. Spatial and topographical factors influence the soil physical properties or the aboveground biomass; the soil physical properties and the biomass control the supply and cycling on $\mathrm{N}$ in the soil (Akiyama and Tsuruta, 2002; Hartley and Schlesinger, 2000; Kirkman et al., 2001; Martin and Asner, 2005; Martin et al., 1998, 2003; Meixner et al., 1997). In the KNP the net N mineralization has been shown to change across soil textural sequences, and is highest in the low lying landscape positions, analogous to the "Footslope" position (Bechtold and Naiman, 2006; Scholes et al., 2003). Vegetation has been shown to have an effect on the emission of NO (Aranibar et al., 2004; Davidson, 1991a; Hartley and Schlesinger, 2000; Kirkman et al., 2001; Martin and Asner, 2005; Martin et al., 1998, 2003; Meixner et al., 1997; Ormeci et al., 1999; Otter et al., 1999; Pilegaard et al., 2006; Scholes et al., 1997; Serca et al., 1998; Van der A et al., 2008). This influence can be caused by the effect of:

1. changes in the microclimate under the plant canopy, resulting in spatial heterogeneity in the soil through interacting biological and physical mechanisms;

2. changes in the concentrations of soil nutrients; N, P and $\mathrm{K}$ have been shown to be enhanced under tree canopies, resulting from the relocation of absorbed nutrients and changes in the $\mathrm{N}$ mineralisation rates (Rossi and Villagra, 2003). The increase in nutrient contents under vegetation is either caused by the vegetation trapping or accumulating nutrients (Ludwig and Tongway, 1995; Ludwig et al., 1999), or through biological $\mathrm{N}$ fixation (Geesing et al., 2000; Schulze et al., 1991; Vitousek et al., 2002).

At the Skukuza flux tower site, the differences in the vegetation types along the catenal sequence have caused a significant difference in the amount of biological $\mathrm{N}$ fixation between the vegetation types. In the Combretum savanna ("Crest" position) the amount of $\mathrm{N}$ fixed is estimated at $4.8 \mathrm{~kg} \mathrm{ha}^{-1} \mathrm{a}^{-1}$, while in the Acacia savanna ("Footslope" position) it is thought to amount to $21 \mathrm{~kg} \mathrm{ha}^{-1} \mathrm{a}^{-1}$ (Scholes et al., 2003). Although the vegetation type has a marked influence on the biological $\mathrm{N}$ fixation, the deposition of $\mathrm{N}$ from the atmosphere in the form of both wet and dry deposition is constant across the vegetation types and amounts to $21.6 \mathrm{~kg} \mathrm{ha}^{-1} \mathrm{a}^{-1}$ (Scholes et al., 2003).

These differences in the $\mathrm{N}$ cycling rate, the total amount of $\mathrm{N}$ in the system, and the amount of $\mathrm{N}$ entering the system by deposition from the atmosphere and biological nitrogen fixation, most likely account for the changes in the magnitude of the observed net potential NO flux. In this study there were clear differences in the NO production potential for the soils from the differing landscape positions. The highest potential NO flux occurred in the "Footslope" soils, which have been shown to have the highest total $\mathrm{N}$ content and $\mathrm{N}$ fixation rate. The lowest $\mathrm{N}$ emissions occurred in the less nutrient rich landscape positions (crest position Table 1) (Scholes et al., 2003; Woghiren, 2002). Loss of $\mathrm{N}$ from the ecosystem through the production of $\mathrm{NO}$ is in the range of $0.2-$ $0.8 \mathrm{~kg} \mathrm{ha}^{-1} \mathrm{a}^{-1}$ (Fig. 8) and therefore the loss of $\mathrm{N}$ in the form of NO is between $0.5 \%$ and $2.6 \%$ of the $\mathrm{N}$ that enters the ecosystem through biological $\mathrm{N}$ fixation and wet and dry deposition from the atmosphere.

\subsection{Effect of soil moisture and temperature}

The optimal soil moisture for the emission of NO from the four landscapes in the KNP was found to be between $10 \%$ and 20\% WFPS. The optimal WFPS is the quantity of soil moisture, where the diffusion of NO through the soil is greatest, since diffusion is not limited by excessive soil moisture, while the bacterial metabolism, and therefore production of NO, is not limited by lack of soil moisture (Skopp et al., 1990). The optimum WFPS reported here correspond with the range reported in other studies in southern Africa; reported values lie between, 10\% and 23\% WFPS for a South African Savanna (Otter et al., 1999), a rainfall gradient in the Kalahari (Aranibar et al., 2004) and in Zimbabwe (Kirkman et al., 2001). Our study therefore confirms that the optimal NO flux occurs in a low and quite narrow range of WFPS in Southern African Savanna ecosystems (10-25\%).

The landscape position affects the soil WFPS through changes in drainage and in the water holding capacity of the soil as influenced by the soil texture. Generally over the course of the year the $F_{\text {up-scaled }}$ is higher for the "Footslope" than for the "Crest" or the "Upslope" soils since the soil WFPS is closer to the optimum. However during periods of high rainfall, the highest $F_{\text {up-scaled }}$ came from the soils above the flux tower which drained better, thereby maintaining a low soil moisture state more suitable for the production of NO. The "Crest" and the "Upslope" soils generally followed a similar pattern, although the $F_{\text {up-scaled }}$ from the "Upslope" soils tended to be slightly higher (see Fig. 6d).

Many previous studies have reported an exponential increase in soil NO emission with increasing temperature, where the $\mathrm{Q}_{10}$ value is approximately 2 (Kirkman et al., 2001; Levine et al., 1996; Meixner and Yang, 2006; Van 
Dijk et al., 2002), which is similar to the $\mathrm{Q}_{10}$ values reported here (1.55-2.17). However, values of up to 4.6 have reported from the Kalahari (Aranibar et al., 2004) and from shortgrass steppe ecosystems (Martin et al., 1998). Under conditions such as very high temperatures (exceeding $40^{\circ} \mathrm{C}$ ) there may even be a negative relationship the $\mathrm{NO}$ emission and the soil temperature (Passianoto et al., 2004), this indicates that a optimum soil temperature may exist, although due to the selection of incubation temperatures used in this study the position of the optimal temperature could not be determined. In recent studies looking at the soil respiration that have been conducted at this site, it has been noted that the soil WFPS affects the $\mathrm{Q}_{10}$ value in a non-linear fashion, where the temperature response is greater in wet soil than in dry soil (Kutsch et al., 2008). On closer examination, a similar effect can be seen on the $\mathrm{Q}_{10}$ temperature amplification factor of NO from this site (data not shown), however this effect was not consistent across all the soils sampled. In light of the recent paper by Kutsch et al. (2008) it may be worth while examining this effect more closely in subsequent studies.

The interplay between the influence of temperature and soil moisture content results in seasonal and annual patterns of NO emissions, in all the soils the lowest NO fluxes occurred during the southern hemisphere winter months when the soil temperatures were low and increased as the soil temperatures increased in spring (September, October) and remained high during the summer, unless the soil became too wet to allow optimal NO production.

The highest $F_{\text {up-scaled }}$ occurred in 2003 and the lowest in 2004. The year 2003 was a relatively warm dry year which kept the soil WFPS low and in the range of the optimal temperature for NO production however, 2004 was a wet year and the soil was wetter than the optimum for extended periods (see Fig. 6d).

\subsection{NO consumption rate and compensation mixing ratio}

It is known that soils can both produce and consume NO, however there have been only a very few studies that have examined the uptake of NO in the soil, and none that have investigated the NO consumption rate constant $(k)$ or the compensation point mixing ratio $\left(\mathrm{m}_{\mathrm{NO}}\right.$,comp $)$ across the full range of soil water contents.

The $k$ value found in this study is within the (very wide) range of values reported in the literature. The peak $k$ value was found to be at the same WFPS as the peak of NO production, between 10-20\% WFPS and ranged between 5 and $26 \times 10^{-5} \mathrm{~m}^{-3} \mathrm{~s}^{-1} \mathrm{~kg}^{-1}$ at $25^{\circ} \mathrm{C}$ (Fig. 4). At $35^{\circ} \mathrm{C}$ it was considerably lower for all the soil samples, less than $7 \times 10^{-5} \mathrm{~m}^{-3} \mathrm{~s}^{-1} \mathrm{~kg}^{-1}$. The highest $k$ values were found in the "Footslope" soils, followed by the "Crest" soils. However, it appears to be a significant difference between the 2 midslope positions ("Upslope" and "Downslope"). To the best of our knowledge, there have only been four previous reports of $k$ from drylands; these are from Nylsvley savanna in South Africa (Otter et al., 1999), from the Kalahari transect in Botswana (Aranibar et al., 2004), from a study in Zimbabwe (Kirkman et al., 2001), and concerning an Egyptian soil (Saad and Conrad, 1993). The $k$ values found in our KNP soils were at least twice as high as those from the Nylsvley savanna and the Zimbabwe study where $k$ values of $1.3-3.2 \times 10^{-5} \mathrm{~m}^{-3} \mathrm{~s}^{-1} \mathrm{~kg}^{-1}$ are reported. In comparison, however, the $k$ values reported from the Kalahari were up to two orders of magnitude higher than from the soils used in this study and ranged from $34-500 \times 10^{-5} \mathrm{~m}^{-3} \mathrm{~s}^{-1} \mathrm{~kg}^{-1}$ (Aranibar et al., 2004). The $k$ values reported in the Egyptian soils ranged from $7.2 \times 10^{-5} \mathrm{~m}^{-3} \mathrm{~s}^{-1} \mathrm{~kg}^{-1}$ at $7^{\circ} \mathrm{C}$ to $79 \times 10^{-5} \mathrm{~m}^{-3} \mathrm{~s}^{-1} \mathrm{~kg}^{-1}$ at 25 and $30^{\circ} \mathrm{C}$ and $40 \%$ water holding capacity (Saad and Conrad, 1993). The $k$ values reported here fit right between the ranges of values previously reported. This, however, is the first time that the $k$ values have been reported across a full soil moisture scale; therefore, the cause of the wide range in reported $k$ values may be that previous measurements were made at different points along the soil moisture range. Soil temperature also has an effect on the $k$ values, although the Nylsvley, Kalahari transect and Zimbabwe studies all used an incubation temperature of $25^{\circ} \mathrm{C}$.

The compensation point mixing ratio, $\mathrm{m}_{\mathrm{NO}}$,comp, has only been investigated in three studies in southern Africa:

1. $\mathrm{m}_{\mathrm{NO} \text {,comp }}$ of $152-157 \mathrm{ppb}$ have been reported from Nylsvley (Otter et al., 1999).

2. along a precipitation gradient in the Kalahari, the $m_{\mathrm{NO}, \text { comp }}$ was reported to change with mean annual precipitation from $39 \mathrm{ppb}$ at Tshane (365 mm Mean Annual Precipitation (MAP)) to $873 \mathrm{ppb}$ for Mongu $(880 \mathrm{~mm}$ MAP) (Aranibar et al., 2004),

3. Kirkman et al. (2001) reported that $M_{\mathrm{NO}}$,comp ranged from 5-11 ppb in the dry season in Zimbabwe and from $47-85 \mathrm{ppb}$ during the wet season.

Our study, however, is the first to examine the effect of soil moisture on the $m_{\mathrm{NO} \text {,comp }}$ covering as extensive a range of soil moisture contents. Within the WFPS range of the NO emission peak, the calculated $m_{\mathrm{NO}}$,comp in our study are between $40-70 \mathrm{ppb}$. Towards higher soil moisture conditions the compensation point mixing ratio decreases gradually to approx. $10 \mathrm{ppb}$ (at 65\% WFPS, see Fig. 4). The results of our study are within the range of values reported for Zimbabwe and Tshane (Kalahari), but much lower than those from Nylsvley and Mongu (Kalahari).

Knowing the WFPS dependent NO compensation point mixing ratios for the different Skukuza land types (as well as the average WFPS itself), the question could be tackled, whether the soils in KNP might ever act as a NO sink. The measured mean monthly WFPS at the Crest position ranges between 10-30\% (Fig. 6c). NO uptake would only occur (cf. Eqs. (5) and (12)), if the ambient NO mixing ratio would 
be higher than $m_{\mathrm{NO}}$,comp there (45-50 ppb, see Fig. 5). For the "Footslope" soils the recorded WFPS in the field occasionally reached levels of $60 \%$ (see Fig. 6c). Under these rather wet conditions the ambient concentration of NO, required before uptake could occur, would be much lower, only approximately $20 \mathrm{ppb}$. However, even an ambient NO mixing ratio of $20 \mathrm{ppb}$ would be exceptionally high for such a remote location. Unfortunately, there are no measured data of ambient NO mixing ratio from Skukuza nor from the entire KNP region available. However, for comparable southern African sites, like Marondera in Zimbabwe, NO mixing ratios of $0.15-0.3 \mathrm{ppb}$ have been reported (Meixner et al., 1997); aircraft measurements in the atmospheric boundary layer over northern Namibia revealed NO mixing ratios well below $0.5 \mathrm{ppb}$, even under conditions of high biogenic soil emissions (approx. $30 \mathrm{ng} \mathrm{m}^{-2} \mathrm{~s}^{-1}$, see Harris et al., 1996). Using the Max Planck Institute for Chemistry Atmospheric Chemistry Model MESSy ("Modular Earth Sub-model System", Jockel et al., 2005), it was found that the modelled surface NO mixing ratio never exceeded $5 \mathrm{ppb}$, and that the mean NO mixing ratio was $0.08 \mathrm{ppb}$ for the period January 2003-October 2005. It is therefore highly unlikely that the ambient NO mixing ratio has exceeded the $m_{\mathrm{NO}}$,comp during 2003-2005. Considering the remoteness of the KNP region and the well established status as a National Park, it can be expected, that the KNP region is continuously acting as a biogenic NO source and not as a sink (like the majority of the southern African savanna ecosystems).

\section{Conclusions}

This laboratory study investigated the biogenic emission of NO from soils taken from four differing landscape positions in a semi-arid savanna under conservation land use (Skukuza, Kruger National Park, South Africa). The up-scaled emissions of NO did not exceed $3.5 \mathrm{ng} \mathrm{m}^{-2} \mathrm{~s}^{-2}$ for any of the landscape positions, even under optimal soil moisture conditions and high soil temperature; this is at the lower end of the range of previously published studies from comparable ecosystems. The optimum emission of NO occurred under fairly low soil water contents, between 10-20\% WFPS. The highest NO flux came from the nutrient rich fine textured soils in the "Footslope" position, while the "Downslope", "Upslope" and "Crest" positions had lower rates of NO emission. When the laboratory derived, net potential NO fluxes were up-scaled to the landscape level, the highest estimated NO fluxes were calculated to come from the sum of "Downslope" and "Upslope" landscape positions, because they make up the majority of the Skukuza landscape surface area. The biogenic emissions of NO from this ecosystem constitute a minor $\mathrm{N}$ loss mechanism and account for less than $2.6 \%$ of the $\mathrm{N}$ entering the system in the form of wet/ dry deposition and biological $\mathrm{N}$ fixation. Although soils have generally both, the potential to emit and to take up atmospheric NO, the ambient atmospheric NO mixing ratios in this remote part of Africa are highly unlikely to reach and exceed that level (i.e. the NO compensation point mixing ratio), where up-take of NO will take place. The laboratory based estimation of soil moisture and soil temperature dependent net potential NO fluxes from soil and the up-scaling procedure (using recorded soil moisture and temperature data from the field) is shown to be an effective method to quantify biogenic NO emissions on large temporal (annual) and spatial (regional) scales.

Acknowledgements. The research of Gregor Feig was made possible by a bursary from the German Academic Exchange Service (DAAD). We would like to thank: Nikki Fisher and Mary Scholes for collecting the soil; staff at Scientific Services for assistance in the field; the Kruger National Park GIS Laboratory, Scientific Services for allowing us access to their GIS data bases, and the Council for Scientific and Industrial Research for providing us with the Skukuza flux tower data. We would also like to thank the four anonymous reviewers, for their useful comments and suggestions.

Edited by: G. Pinay

\section{References}

Akiyama, H. and Tsuruta, H.: Effect of chemical fertilizer form on $\mathrm{N}_{2} \mathrm{O}, \mathrm{NO}$ an $\mathrm{NO}_{2}$ fluxes from andisol field, Nutrient Cycling Agroecosystems, 63, 219-230, 2002.

Anderson, J. M. and Ingram, J. S. I.: Tropical Soil Biology and Fertility A Handbook of Methods, CAB International, Wallingford, 1993.

Aranibar, J. N., Otter, L. B., Macko, S. A., Feral, C. J. W., Epstein, H. E., Dowty, P. R., Eckardt, F. D., Shugart, H. H., and Swap, R. $\mathrm{J}$.: Nitrogen cycling in the soil-plant system along a precipitation gradient in the Kalahari sands, Glob. Change Biol., 10, 359-373, 2004.

Barger, N. N., Belnap, J., Ojima, D. S., and Mosier, A. R.: NO gas loss from biologically crusted soils in Canyonlands National Park, Utah, Biogeochemistry, 75, 373-391, 2005.

Bechtold, J. S. and Naiman, R. J.: Soil texture and nitrogen mineralization potential across a riparian toposequence in a semi-arid savanna, Soil Biol. Biochem., 38(5), 1325-1333, 2006.

Chameides, W. L., Fehsenfeld, F., Rodgers, M. O., Cardelino, C., Martinez, J., Parrish, D., Lonneman, W., Lawson, D. R., Rasmussen, R. A., Zimmerman, P., Greenberg, J., Middleton, P., and Wang, T.: Ozone precursor relationships in the ambient atmosphere, J. Geophys. Res., 92, 6037-6055, 1992.

Conrad, R.: Compensation concentration as critical variable for regulating the flux of trace gases between soil and atmosphere, Biogeochemistry, 27, 155-170, 1994.

Conrad, R.: Soil Microbial Processes and the Cycling of Atmospheric Trace Gases, Philos. Tr. R. Soc. S.-A, 351(1696), 219230, 1995.

Conrad, R.: Soil Microorganisms as controllers of atmospheric trace gases $\left(\mathrm{H}_{2}, \mathrm{CO}, \mathrm{CH}_{4}, \mathrm{~N}_{2} \mathrm{O}\right.$ and $\left.\mathrm{NO}\right)$, Microbiol. Rev., 60(4), 609-640, 1996.

Coyne, M. S.: Soil Microbiology: An exploratory approach, 462 pp., Delmar Publishers, Albany, 1999. 
Crutzen, P. J.: Overview of tropospheric chemistry: Developments during the past quarter century and a look ahead, Faraday Discuss., 100, 1-21, 1995.

Crutzen, P. J. and Lelieveld, J.: Human impacts on atmospheric chemistry, Annual Review of Earth and Planetary Sciences, 29, 17-45, 2001.

Davidson, E. A.: Fluxes of nitrous oxide and nitric oxide from terrestrial ecosystems, in: Microbial production and consumption of Greenhouse Gases: Methane, Nitrogen Oxides and Halomethanes, edited by: Rogers, J. E. and Whitman, W. B., American Society for Microbiology, Washington DC, 219-235, 1991a.

Davidson, E. A.: Soil Water content and the ratio of nitrous oxide to nitric oxide emitted from soil, in: Tenth International symposium on environmental biogeochemistry, Chapman and Hall, San Francisco, 369-386, 1991b.

Davidson, E. A. and Kingerlee, W.: A global inventory of nitric oxide emissions from soils, Nutr. Cycl. Agroecosys., 48, 37-50, 1997.

Davidson, E. A., Matson, P. A., Vitousek, P. M., Riley, R., Dunkin, D., Garcia-Mendez, G., and Maass, J. M.: Processes regulating soil emissions of $\mathrm{NO}$ and $\mathrm{N}_{2} \mathrm{O}$ in a seasonally dry tropical forest, Ecology, 74(1), 130-139, 1993.

Day, P. R.: Particle fractionation and particle-size analysis, in: Methods of soil analysis Part 1: Physical and mineralogical properties, including statistics of measurements and sampling, edited by: Black, C. A., Evens, D. D., Ensminger, L. E., White, J. L., and Clark, F. E., American Society of Agronomy, Madison, 545567, 1969

Denman, K. L., Brasseur, G. P., Chidthaisong, A., Ciais, P., Cox, P. M., Dickinson, R. E., Hauglustaine, D., Heinze, C., Holland, E. A., Jacob, D. J., Lohmann, U., Ramachandran, S., da Silva Dias, P. L., Wofsy, S. C., and Zhang, X.: Couplings between changes in the climate system and biogeochemistry, in: Climate Change 2007: The physical science basis. contribution of working group 1 to the fourth assessment report of the Intergovernmental Panel on Climate Change, edited by: Solomon, S., Qin, D., Manning, M., Chen, Z., Marquis, M., Averyt, K. B., Tignor, M., and Miller, H. L., Cambridge University Press, Cambridge, 499-588, 2007.

Erickson, H., Davidson, E. A., and Keller, M.: Former land-use and tree species affect nitrogen oxide emissions from a tropical dry forest, Oecologia, 130, 297-308, 2002.

Erickson, H., Keller, M., and Davidson, E. A.: Nitrogen oxide fluxes and nitrogen cycling during post agricultural succession and forest fertilization in the humid tropics, Ecosystems, 4, 6784, 2001.

Feig, G.T., M.C. Scholes, L.B. Otter, and B. Vanlauwe, Nitrogen in Africa, in: Global Climatic Change Processes and their impact on Africa: A Synthesis, edited by: Otter, L. B., Olago, D. O., and Niang, I., East Africa Educational Publishers, Nairobi, 217243, 2007.

Galloway, J. N., Bekunda, M. A., Cai, Z., Erisman, J. W., Freney, J., Howarth, R. W., Martinelli, L., Scholes, M. C., and Seitzinger, S. P.: A preliminary assessment of "changes in the global nitrogen cycle as a result of anthropogenic influences", International Nitrogen Initiative, 1-33, 2004.

Garrido, F., Henault, C., Gaillard, H., Perez, S., and Germon, J. C.: $\mathrm{N}_{2} \mathrm{O}$ and $\mathrm{NO}$ emissions by agricultural soils with low hydraulic potentials, Soil Biol. Biochem., 34, 559-575, 2002.
Geesing, D., Felker, P., and Bingham, R. L.: Influence of mesquite (Prosopis glandulosa) on soil nitrogen and carbon development: Implications for global carbon sequestration, J. Arid Environ., 46, 157-180, 2000.

Gut, A., Blatter, A., Fahrni, M., Lehmann, B. E., Neftel, A., and Staffelbach, T.: A new membrane tube technique (METT) for continuous gas measurements in soil, Plant Soil, 198, 79-88, 1998.

Hall, S. J., Huber, D., and Grimm, N. B.: Soil N2O and NO emissions from an arid, urban ecosystem, J. Geophys. Res.Biogeosciences, 113(G1), G01016, doi:10.1029/2007JG000523, 2008.

Harley, P., Otter, L. B., Guenther, A., and Greenberg, J.: Micrometeorological and leaf-level measurements of isoprene emissions from a southern African savanna, J. Geophys. Res., 108(D13), 8468, doi:10.1029/2002JD002592, 2003.

Harris, G. W., Weinhold, F. G., and Zenker, T.: Airborne observations of strong biogenic $\mathrm{NO}_{\mathrm{x}}$ emissions from the Namibian Savanna at the end of the dry season, J. Geophys. Res., 101, 707$712,1996$.

Hartley, A. E. and Schlesinger, W. H.: Environmental controls on nitric oxide emission from northern Chihauhuan desert soils, Biogeochemistry, 50, 279-300, 2000.

Holst, J., Liu, C. Y., Bruggemann, N., Butterbach-Bahl, K., Zheng, X. H., Wang, Y. S., Han, S. H., Yao, Z. S., Yue, J., and Han, X. G.: Microbial $\mathrm{N}$ turnover and $\mathrm{N}$-oxide $\left(\mathrm{N}_{2} \mathrm{O} / \mathrm{NO} / \mathrm{NO}_{2}\right)$ fluxes in semi-arid grassland of Inner Mongolia, Ecosystems, 10(4), 623634, 2007.

Hutchinson, G. L., Guenzi, W. D., and Livingston, G. P.: Soil water controls on aerobic soil emission of gaseous nitrogen oxides, Soil Biol. Biochem., 25(1), 1-9, 1993.

IPCC: Climate Change 2001: The Scientific Basis, Contribution of Working Group I to the Third Assessment Report of the Intergovernmental Panel on Climate Change (IPCC), in: Chapter 4: Atmospheric Chemistry and Greenhouse Gases, edited by: Houghton, J. T., Ding, Y., Griggs, D. J., Noguer, M., van der Linden, P. J., and Xiaosa, D., Cambridge University Press, Cambridge, New York, 239-287, 2001.

Jockel, P., Sander, R., Kerkweg, A., Tost, H., and Lelieveld, J.: Technical note: The Modular Earth Submodel System (MESSy) - a new approach towards Earth System Modelling, Atmos. Chem. Phys., 5, 433-444, 2005,

http://www.atmos-chem-phys.net/5/433/2005/.

Kasibhatla, P. S., Levy, H., and Moxim, W. J.: Global $\mathrm{NO}_{\mathrm{x}}, \mathrm{HNO}_{3}$, Pan, and $\mathrm{NO}_{\mathrm{y}}$ Distributions from Fossil-Fuel Combustion Emissions - a Model Study, J. Geophys. Res.-Atmos., 98(D4), 71657180, 1993.

Kirkman, G. A., Yang, W. X., and Meixner, F. X.: Biogenic nitric oxide emissions upscaling: an approach for Zimbabwe, Global Biogeochem. Cy., 15(4), 1005-1020, 2001.

Kutsch, W. L., Hanan, N., Scholes, R. J., McHugh, I., Kubheka, W., Eckhardt, H., and Williams, C.: Response of carbon fluxes to water relations in a savanna ecosystem in South Africa, Biogeosciences Discuss., 5(3), 2197-2235, 2008.

Lerman, A.: Water and sediment environments, in: Geochemical Processes, Wiley, New York, 1979.

Levine, J. S., Parsons, D., Zepp, R. G., Burke, R. A., Cahoon, D. R., Cofer, W. R., Miller, W. L., Scholes, M. C., Scholes, R. J., Sebacher, D. I., and Winstead, E. L.: Southern Africa as a source of 
atmospheric gases, in: Fire in southern African savannas, edited by: Van Wilgen, B. W., Andreae, M. O., Goldammer, J. G., and Lindesay, J. A., Witwatersrand University Press, Johannesburg, 135-160, 1997.

Levine, J. S., Winstead, E., Parsons, D. A. B., Scholes, M. C., Scholes, R. J., Cofer, W. R., Cahoon, D. R., and Sebacher, D. I.: Biogenic emissions of nitric oxide (NO) and nitrous oxide $\left(\mathrm{N}_{2} \mathrm{O}\right)$ from savannas in South Africa: The impact of wetting and burning, J. Geophys. Res., 101, 23 683-23 688, 1996.

Lloyd, J. and Taylor, J. A.: On the Temperature-Dependence of Soil Respiration, Funct. Ecol., 8(3), 315-323, 1994.

Logan, J. A.: Nitrogen oxides in the troposphere: global and regional budgets, J. Geophys. Res., 88, 10 785-10 807, 1983.

Ludwig, J., Meixner, F. X., Vogel, B., and Förstner, J.: Soil-air exchange of nitric oxide: An overview of processes, environmental factors, and modelling studies, Biogeochemistry, 52, 225-257, 2001.

Ludwig, J. A. and Tongway, D. J.: Spatial organisation of landscapes and its function in semi-arid woodlands, Australia, Landscape Ecol., 10, 51-63, 1995.

Ludwig, J. A., Tongway, D. J., and Marsden, S. G.: Stripes, strands or stipples: Modelling the influence of three landscape banding patterns on resource capture and productivity in semi-arid woodlands, Australia, Catena, 37, 257-273, 1999.

Martin, R. E. and Asner, G. P.: Regional estimate of nitric oxide emissions following woody encroachment: linking imaging spectroscopy and field studies, Ecosystems, 8, 33-47, 2005.

Martin, R. E., Asner, G. P., Ansley, R. J., and Mosier, A. R.: Effects of woody vegetation encroachment on soil nitric oxide emissions in a temperate savanna, Ecol. Appl., 13(4), 897-910, 2003.

Martin, R. E., Scholes, M. C., Mosier, A. R., Ojima, D. S., Holland, E. A., and Parton, W. J.: Controls on annual emissions of nitric oxide from soils of the Colorado Shortgrass Steppe, Global Biogeochem. Cy., 12(1), 81-91, 1998.

McCalley, C. K., and Sparks, J. P.: Controls over nitric oxide and ammonia emissions from Mojave Desert soils, Oecologia, 156(4), 871-881, 2008.

Meixner, F. X., Fickinger, T., Marufu, L., Serca, D., Nathaus, F. J., Makina, E., Mukurumbira, L., and Andreae, M. O.: Preliminary results on nitric oxide emission from a southern African savanna ecosystem, Nutr. Cycl. Agroecosys., 48, 123-138, 1997.

Meixner, F. X. and Yang, W. X.: Biogenic emissions of nitric oxide and nitrous oxide from arid and semi-arid land, in: Dryland Ecohydrology, edited by: D'Odorico, P. and Porporat, A., Springer, Dordrecht, 233-255, 2006.

Moldrup, P., Olesen, T. R., Gamst, J., Schjonning, P., Yamaguchi, T., and Rolston, D. E.: Predicting the gas diffusion coefficient in repacked soil: Water-induced linear reduction model, Soil Sci. Soc. Am. J., 64, 1588-1584, 2000.

Monks, P. S.: Gas-phase radical chemistry in the troposphere, Chem. Soc. Rev., 34, 376-395, 2005.

Ormeci, B., Sanin, S. L., and Peirce, J. J.: Laboratory study of NO flux from agricultural soil: effects of soil moisture, $\mathrm{pH}$, and temperature, J. Geophys. Res., 104(D1), 1621-1629, 1999.

Otter, L. B., Yang, W. X., Scholes, M. C., and Meixner, F. X.: Nitric Oxide emissions from a southern African Savanna, J. Geophys. Res., 104(D15), 18 471-18 458, 1999.

Parsons, D. A. B., Scholes, M. C., Scholes, R. J., and Levine, J. S.: Biogenic NO emission from savanna soils as a function of fire regime, soil type, soil nitrogen and water status, J. Geophys. Res., 101(D19), 23 683-23 688, 1996.

Parton, W. J., Holland, E. A., Del Grosso, S. J., Hartman, M. D., Martin, R. E., Mosier, A. R., Ojima, D. S., and Schimel, D. S.: Generalized model for $\mathrm{NO}_{\mathrm{x}}$ and $\mathrm{N}_{2} \mathrm{O}$ emissions from soils, J. Geophys. Res., 106(D15), 17 403-17 419, 2001.

Passianoto, C. C., Ahrens, T., Feigl, B. J., Streudler, P. A., Melillo, J. M., and do Carmo, J. B.: Diurnal changes in nitric oxide emissions from conventional tillage and pasture sites in the Amazon Basin: influence of soil temperature, Plant Soil, 258, 21-29, 2004.

Pilegaard, K., Skiba, U., Ambus, P., Beier, C., Buggemann, N., Butterbach-Bahl, K., Dick, J., Dorsey, J., Duyzer, J., Gallagher, M., Gasche, R., Horvarth, L., Kitzler, B., Leip, A., Pihlatie, M. K., Rosenkranz, P., Seufert, G., Vesala, T., Westrate, H., and Zechmeister-Boltenstern, S.: Factors controlling regional differences in forest soil emission of nitrogen oxides ( $\mathrm{NO}$ and $\mathrm{N}_{2} \mathrm{O}$ ), Biogeosciences, 3, 651-661, 2006,

http://www.biogeosciences.net/3/651/2006/.

Remde, A., Ludwig, J., Meixner, F. X., and Conrad, R.: A Study to Explain the Emission of Nitric-Oxide from a Marsh Soil, J. Atmos. Chem., 17(3), 249-275, 1993.

Remde, A., Slemr, F., and Conrad, R.: Microbial production and uptake of nitric oxide in soil, FEMS Microbiol. Ecol., 62, 221230, 1989.

Rossi, B. and Villagra, P. E.: Effects of Prosopis flexuosa on soil properties and the spatial pattern of understorey species in arid Argentina, J. Veg. Sci., 14, 543-550, 2003.

Russow, R., Sich, I., and Neue, H.-U.: The formation of the trace gases $\mathrm{NO}$ and $\mathrm{N}_{2} \mathrm{O}$ in soils by the coupled processes of nitrification and denitrification: results of kinetic ${ }^{15} \mathrm{~N}$ tracer investigations, Chemosphere, 2, 359-366, 2000.

Russow, R., Spott, O., and Stange, C. F.: Evaluation of nitrate and ammonium as sources of $\mathrm{NO}$ and $\mathrm{N}_{2} \mathrm{O}$ emissions from black earth soils (Haplic Chernozem) based on ${ }^{15} \mathrm{~N}$ field experiments, Soil Biology and Biochemistry, 40(2), 380-391, 2008.

Saad, O. A. L. O. and Conrad, R.: Temperature dependence of nitrification, denitrification and turnover of nitric oxide in different soils, Biology and Fertility of Soils, 15, 21-27, 1993.

Scholes, M. C., Martin, R., Scholes, R. J., Parsons, D., and Winstead, E.: $\mathrm{NO}$ and $\mathrm{N}_{2} \mathrm{O}$ emissions from savanna soils following the first simulated rains of the season, Nutrient Cycling in Agroecosystems, 48, 115-122, 1997.

Scholes, M. C., Scholes, R. J., Otter, L. B., and Woghiren, A. J.: Biogeochemistry: The cycling of elements, in: The Kruger experience, ecology and management of savanna heterogeneity, edited by: Du Toit, J. T., Rogers, K. H., and Biggs, H. C., Island Press, Washington, 130-148, 2003.

Scholes, R. J., Gureja, N. G., Giannecchinni, M., Dovie, D., Wilson, B., Davidson, N., McLoughlin, K. C., Van der Velde, K., Freeman, A., Bradley, S., Smart, R., and Ndala, S.: The environment and vegetation of the flux measurement site near Skukuza, Kruger National Park, Koedoe, 44(1), 73-83, 2001.

Schulze, E. D., Gebauer, G., Ziegler, H., and Lange, O. L.: Estimation of $\mathrm{N}$ fixation by trees on an aridity gradient in Namibia, Oecologia, 88, 451-455, 1991.

Serca, D., Delmas, R., Le Roux, X., Parsons, D. A. B., Scholes, M. C., Abbadie, L., Lensi, R., Ronce, O., and Labroue, L.: Comparison of nitrogen monoxide emissions from several African 
tropical ecosystems and influence of season and fire, Global Biogeochem. Cy., 12(4), 637-651, 1998.

Skopp, J., Jawson, M. D., and Doran, J. W.: Steady-State Aerobic Microbial Activity as a Function of Soil-Water Content, Soil Sci. Soc. Am. J., 54(5), 1619-1625, 1990.

Smart, D. R., Stark, J. M., and Deigo, V.: Resource limitation to nitric oxide emissions from a sagebrush-steppe ecosystem, Biogeochemistry, 47, 63-86, 1999.

Snyder, K. A. and Tartowski, S. L.: Multi-scale temporal variation in water availability: Implications for vegetation dynamics in arid and semi-arid ecosystems, J. Arid Environ., 65, 219-234, 2006.

Stehfest, E. and Bouwman, L.: $\mathrm{N}_{2} \mathrm{O}$ and $\mathrm{NO}$ emissions from agricultural fields and soils under natural vegetation: summarizing available measurement data and modelling of global annual emissions, Nutr. Cycl. Agroecosys., 74, 207-228, 2006.

Tabachow, R. M., Peirce, J. J., and Essiger, C.: Hurricane-Loaded soil: effects on nitric oxide emissions from soil, J. Environ. Qual., 30, 1904-1910, 2001.

Van der A, R. J., Eskes, H. A., Boersma, K. F., Van Noije, T., van Roozendael, M., De Smedt, I., Peters, D. H. M. U., and Meijer, E. W.: Trends, seasonal variability and dominant $\mathrm{NO}_{\mathrm{x}}$ source derived from a ten year record of $\mathrm{NO}_{2}$ measured from space, J. Geophys. Res., 113, D04302, doi:10.1029/2007JD009021, 2008.
Van Dijk, S. M., Gut, A., Kirkman, G. A., Meixner, F. X., and Andreae, M. O.: Biogenic NO emissions from forest and pasture soils: Relating laboratory studies to field measurements, J. Geophys. Res., 107(D20), LBA25, doi:10.1029/2001JD000358, 2002.

Venter, F. J., Scholes, R. J., and Eckhardt, H. C.: The abiotic template and its associated vegetation patterns, in: The Kruger experience ecology and management of savanna heterogeneity, edited by: Du Toit, J. T., Rogers, K. H., and Biggs, H. C., Island Press, Washington, 83-129, 2003.

Veron, S. R., Paruelo, J. M., and Oesterheld, M.: Assessing desertification, J. Arid Environ., 66, 751-763, 2006.

Vitousek, P. M., Cassman, K., Cleveland, C. C., Crews, T., Field, C. B., Grimm, N. B., Howarth, R. W., Marino, R., Martinelli, L., Rastetter, E. B., and Sprent, J. I.: Towards an ecological understanding of biological nitrogen fixation, Biogeochemistry, 57/58, $1-45,2002$.

Woghiren, A. J.: Nitrogen characterisation of the savanna flux site at Skukuza, Kruger National Park, MSc thesis, University of the Witwatersrand, Johannesburg, 2002. 